Hoffmann Jasper, Justus Lutz (Orcid ID: 0000-0002-0724-0790)

Schröder Jan, Frederik (Orcid ID: 0000-0003-0432-5593)

Schmidt Mark (Orcid ID: 0000-0002-4298-9617)

Gorman Andrew, Robert (Orcid ID: 0000-0002-8581-0197)

\title{
Complex eyed pockmarks and submarine groundwater discharge revealed by acoustic data and sediment cores in Eckernförde Bay, SW Baltic Sea
}

\section{J.J.L. Hoffmann ${ }^{1}$, J. Schneider von Deimling², J. F. Schröder ${ }^{2}$, M. Schmidt ${ }^{3}$, P. Held ${ }^{2}$, G.} J. Crutchley ${ }^{3}$, J. Scholten ${ }^{2}$, A. R. Gorman ${ }^{1}$

${ }^{1}$ University of Otago, Department of Geology, PO Box 56, Dunedin 9054, New Zealand

2 University of Kiel, Institute of Geosciences, Otto-Hahn-Platz 1, 24118 Kiel, Germany

${ }^{3}$ GEOMAR - Helmholtz Centre for Ocean Research Kiel, Wischhofstraße 1-3, 24148 Kiel, Germany

Corresponding author: Jasper Hoffmann (Jasper.Hoffmann@otago.ac.nz)

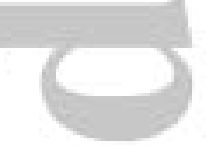

\section{Key Points:}

- We present a new form of eyed pockmarks caused by shallow gas

- We establish acoustic indicators for submarine groundwater discharge associated with gas

\section{Keywords:}

Submarine groundwater discharge (SGD), Pockmarks, Shallow gas, Hydroacoustics, Backscatter

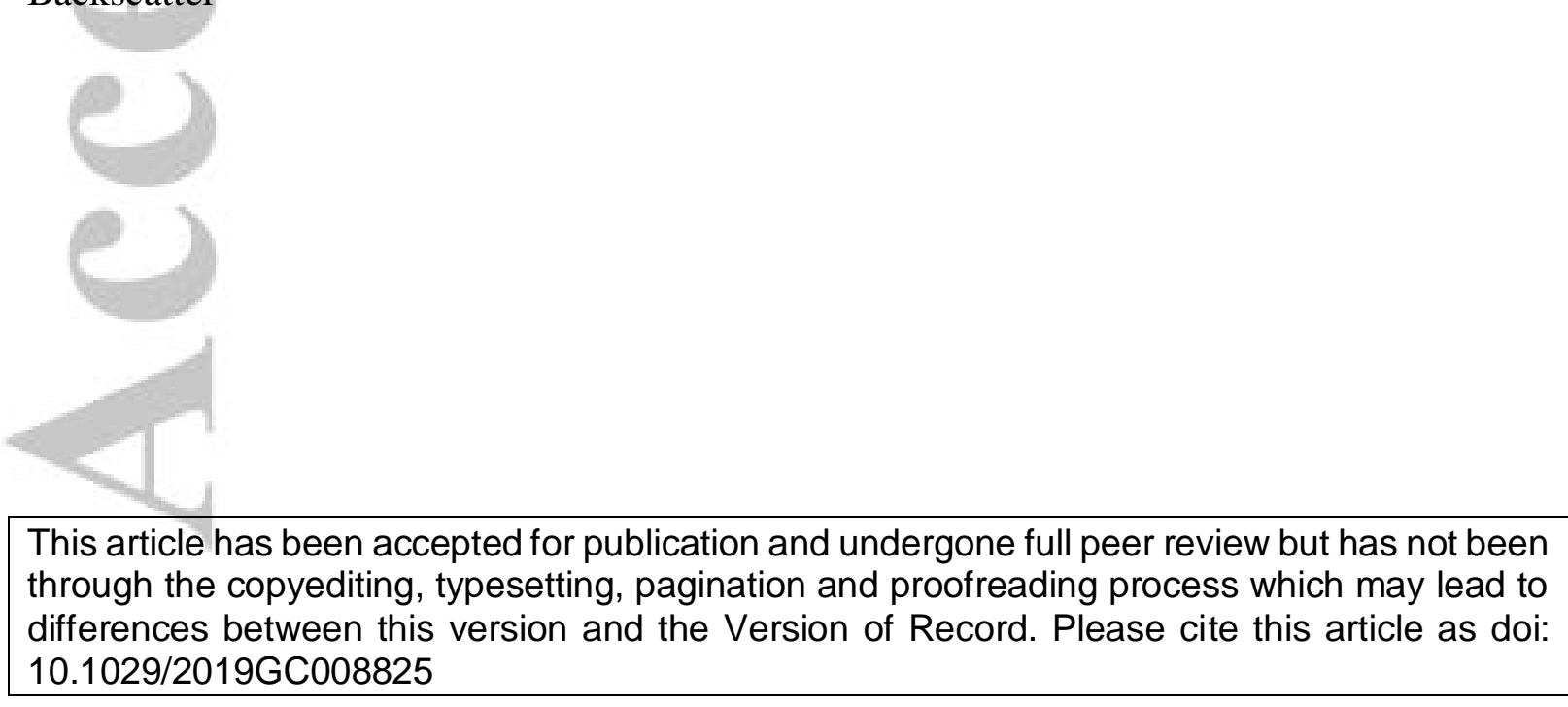




\begin{abstract}
:
Submarine groundwater discharge (SGD) into coastal areas is a common global phenomenon and is rapidly gaining scientific interest due to its influence on marine ecology, the coastal sedimentary environment and its potential as a future freshwater resource. We conducted an integrated study of hydroacoustic surveys combined with geochemical porewater and water column investigations at a well-known groundwater seep site in Eckernförde Bay (Germany). We aim to better constrain the effects of shallow gas and SGD on high frequency multibeam backscatter data and to present acoustic indications for submarine groundwater discharge. Our high-quality hydroacoustic data reveal hitherto unknown internal structures within the pockmarks in Eckernförde Bay. Using precisely positioned sediment core samples, our hydroacoustic-geochemical approach can differentiate intra-pockmark regimes that were formerly assigned to pockmarks of a different nature. We demonstrate that high-frequency multibeam data, in particular the backscatter signals, can be used to detect shallow free gas in areas of enhanced groundwater advection in muddy sediments. Intriguingly, our data reveal relatively small (typically $<15 \mathrm{~m}$ across) pockmarks within the much larger, previously mapped, pockmarks. The small pockmarks, which we refer to as "intra-pockmarks", have formed due to the localized ascent of gas and groundwater; they manifest themselves as a new type of 'eyed' pockmarks, revealed by their acoustic backscatter pattern. Our data suggest that, in organic-rich muddy sediments, morphological lows combined with a strong multibeam backscatter signal can be indicative of free shallow gas and subsequent advective groundwater flow.
\end{abstract}

\title{
Plain Language Summary
}

Groundwater that seeps out of the ocean floor is a common global phenomenon. Marine ecosystems are highly dependent on nutrient supply from land and recent studies have suggested that groundwater seeping out of the seafloor supplies even more nutrients to the world's oceans than rivers do. Also, nearshore freshwater springs have been used as a source of drinking water for decades and large offshore groundwater reserves in continental shelfs can potentially prevent future freshwater shortages. We use echo-sounding methods to search for indications for submarine groundwater. The methods enable us to carry out detailed investigations of intriguing seafloor depressions (i.e. "pockmarks"). Our accurate measurements give new insights into the morphology and characterisation of the Eckernförde Bay pockmarks and reveal a new type of pockmark that is related to seeping groundwater. In the muddy sediment of Eckernförde Bay, methane gas forms in the sediments due to microbial decomposition of biomass. In areas of enhanced groundwater advection, this methane gas is brought closer to the seafloor, where pockmarks form, and where we can detect the gas with our sonar system. Given the abundant global distribution of muddy gaseous sediments, our findings have important implications for the future detection of offshore groundwater systems.

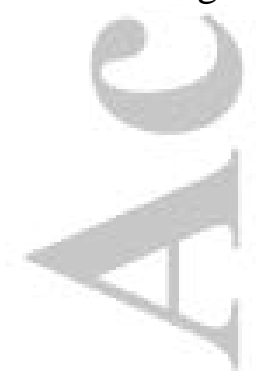




\section{Introduction}

Escalating water demand in coastal areas and the nature and dynamics of interconnected onshore and offshore aquifers have significantly increased scientific interest in submarine groundwater discharge (SGD) over recent decades. SGD often carries large amounts of nutrients into to sea with diverse implications for the coastal ecosystems and environments (Lecher et al., 2016; Moore, 2010). Cho et al. (2018) estimated that the global nutrient flux into the oceans through SGD even exceeds riverine inputs. Future climate change, and in particular an expected increased frequency of global droughts (IPCC, 2014; Seager et al., 2007), have provided traction to research into offshore groundwater reserves as a possible source of potable and agricultural water (Berndt \& Micallef, 2019). Therefore, cost- and time-effective detection and characterisation of submarine groundwater systems, the dynamics of their discharge, and their temporal and spatial variation, are crucial for a potential exploitation in the future.

Numerous methods have been used to detect and quantify SGD (Burnett et al., 2006) including optical systems (Karpen et al., 2004), geochemical water-column investigations of tracers like the natural radionuclides radium and radon (Burnett \& Dulaiova, 2003; Moore, 1996; Moore et al., 2008; Scholten et al., 2013), dissolved silicon (Oehler et al., 2019), methane and chloride (Dulaiova et al., 2010; Schlüter et al., 2004), as well as remote sensing (Shaban et al., 2005; Tamborski et al., 2015; Wilson \& Rocha, 2012) and direct investigations using cores and different types of seepage meters (Bugna et al., 1996; Burnett \& Dulaiova, 2003; Cable et al., 1997; Sauter et al., 2001). Only a few geophysical methods, like geoelectric (Stieglitz, 2005; Viso et al., 2010), controlled source electromagnetic (CSEM) (Gustafson et al., 2019; Müller et al., 2011), or autonomous underwater vehicle (AUV) investigations (Sauter et al., 2003) have been used to explore SGD. Other hydroacoustic studies often postulate SGD solely based on geomorphological characteristics, but without any geochemical verification (e.g. Goff, 2019; Hillman et al., 2015; Jakobsson et al., 2020).

Submarine hydrocarbon seeps likewise attract much interest because of the specific micro-environments they create at the seafloor (Berndt, 2005; Judd \& Hovland, 2009) and their influence on slope stability (Chapron et al., 2004; Riboulot et al., 2019), representing a risk to infrastructure (Cayocca et al., 2001; Mulder \& Chochonat, 1996). Since they often emit methane, a potent greenhouse gas, they can contribute to climate change and exacerbate symptoms of global warming like ocean acidification and oxygen depletion in the oceans (Biastoch et al., 2011; Borges et al., 2016; Leifer et al., 2006; Solomon et al., 2009).

In Eckernförde Bay, sulfate reduction is the dominant process for organic carbon degradation in the upper $-30 \mathrm{~cm}$ below the seafloor before the sulfate is depleted (Maltby et al., 2018). Below the sulfate-methane transition zone (SMTZ) methanogenesis leads to methane oversaturation and gas formation in the organic-rich mud, resulting in widespread acoustic turbidity zones (Figure 1). Several pockmarks form along the coastlines as well as in the central part of Eckernförde around Mittelgrund as a result of gas and submarine groundwater seepage (Bussmann \& Suess, 1998; Jensen et al., 2002; Kaleris et al., 2002; Müller et al., 2011; Patiris et al., 2018; Schlüter et al., 2004; Whiticar, 2002). We define a pockmark according to Judd \& Hovland (2009) as a seafloor depression of erosive nature with an eroding agent that comes from beneath the seabed. In Eckernförde bay questions remain regarding the fluid contributions to pockmark formation as well as the different pockmark classifications given by different authors (Albert et al., 1998; Whiticar, 2002). Although numerous research cruises and international research projects (e.g., Coastal Benthic Boundary Layer (CBBL), Submarine Groundwater Fluxes and Transport Processes from 
Methane-Rich Coastal Sedimentary Environment (Sub-GATE)) have investigated the geological, geomechanical, geochemical and geophysical background of the pockmarks and their host sediments, the internal pockmark geomorphology is still poorly constrained. Sidescan and multibeam data published by Sauter et al. (2003) and Schlüter et al. (2004) show the delineation and depth of the pockmarks but are unable to reveal their internal structure and morphology.

In this paper, we investigate the geomorphological expressions of SGD and gas escape as well as the subbottom characteristics within the pockmarks in Eckernförde Bay. We conducted hydroacoustic surveys using multi-frequency singlebeam, multibeam and subbottom profiler data in 2014, 2017, 2018 and 2019 and ground truth observations from these data with porewater geochemistry from 13 sediment cores as well as CTD casts and transects of the water column. This high-frequency (up to $400 \mathrm{kHz}$ ) study, on the one hand, provides very high-resolution bathymetry enabling us to acquire targeted and accurately positioned sediment cores for porewater-analysis and groundtruthing. On the other hand, the high frequency has limited but significant seafloor penetration and therefore provides subsurface information. We investigate a new type of pockmark associated with SGD in gaseous mud. Hovland et al. (2002) described complex- unit- and eyed-pockmarks but a combination of them has not been reported previously. Our aim is to improve the characterisation of pockmarks forming by SGD and gas, and to determine possible acoustic indications for groundwater discharge in regions of organic-rich gaseous mud.

\section{Geological setting}

The $17 \mathrm{~km}$ long and $3 \mathrm{~km}$ wide Eckernförde Bay is located in the western Baltic Sea and was mainly shaped during the end of the Weichselian glaciation about 13,000 yr BP. The mouth of Eckernförde Bay is divided into a deeper northern entrance and a shallower southern channel by a morainal sill called Mittelgrund (Figure 1). Sediment grain-size distribution in Eckernförde Bay gradually decreases with increasing water depth (Seibold et al., 1971; Werner et al., 1987). The sediments are mainly derived from the retreating till cliffs surrounding the bay with a minor amount contributed by the abrasion of Mittelgrund (Healy \& Wefer, 1980; Healy \& Werner, 1987).

Mean sedimentation rates in the central basin of 4.2 and $3.9 \mathrm{~mm} / \mathrm{yr}$ were reported by Balzer et al. (1987) and Nittrouer et al. (1998), respectively; however, Milkert and Werner (1997) and Balzer et al. (1987) show that strong temporal fluctuations occur with sedimentation rates of up to $10 \mathrm{~mm} / \mathrm{yr}$. In the inner part of Eckernförde Bay, high Corg accumulation rates originate mainly from marine plankton and macroalgal sources (Balzer, 1984; Koegler, 1967). The high organic matter content (between 4 and 5\%) of surface sediments together with seasonally hypoxic bottom water, leads to strong anoxic conditions, a rapid decrease of sulfate and the onset of methanogenesis in the sediment within a few centimetres below the seafloor (Maltby et al., 2018; Steinle et al., 2017; Treude et al., 2005; Whiticar, 2002). Sediments below 20-22 m water depths consist mainly of Holocene mud deposited after the Littorina transgression (< 8000 yr BP (Rößler, 2006)) with gaseous (i.e., methane) sediments of microbial origin below $\sim 0.5-3 \mathrm{~m}$ (Martens et al., 1999; Schüler, 1952; Wever et al., 1998, 2006; Whiticar \& Werner, 1981). This interstitial gas results in the characteristic acoustic turbidity zone (first described as the "Becken-Effect" by Hinz et al. (1971)) commonly found in many shallow seas and lakes.

Although the bay is only minimally affected by tides, strong surface currents and sealevel changes can occur due to wind forcing, storm surges and the effect of seiches (Dietrich, 
1951; Khandriche et al., 1987; Orsi et al., 1996). Bottom currents of up to $55 \mathrm{~cm} / \mathrm{s}, 4 \mathrm{~m}$ above the seafloor, have been reported to follow storm surges (Geyer, 1964). The water column in Eckernförde Bay is generally well stratified with pycnoclines forming due to strong variations of salinity and temperature, caused by the inflow of salty North Sea waters underneath the fresher and warmer surface water (Bange et al., 2011). This stratification becomes less pronounced over winter when cold surface waters and storms mix the entire water column (Smetacek, 1985; Smetacek et al., 1987).

Several aquifers have been attributed to supply groundwater into the bay. Bussmann and Suess (1998) and Wever et al. (1998) attributed the origin of this groundwater to the major Miocene lignite sand aquifer which reaches a thickness of 100-130 m on the southern side of the bay in $\sim 100 \mathrm{~m}$ depth and is hydraulically connected to shallower aquifers (Marczinek \& Piotrowski, 2002). These shallower 10-15 m thick Pleistocene sand aquifers occur between two till units (Jensen et al., 2002). In the coastal area south of the bay, another few-meters-thick late Pleistocene to Holocene sand aquifer is sealed by late glacial clays, glacio-lacustrine silts and till. Jensen et al. (2002) and Whiticar (2002) concluded, that SGD into the Eckernförde Bay is related to marginal areas where the late-glacial seal is thinned, and the Holocene mud coverage is weak enough to be penetrated by artesian groundwater.

\section{Data}

\subsection{Multibeam echo sounder (MBES)}

The MBES data used in this study were repeat surveys of the pockmarks carried out over a 4.5-year period. The data were acquired on R/V Alkor and R/V Littorina during three surveys in October-November 2014 (cruise AL447), August 2017 (cruise AL501) and May 2019 (cruise L1905).Three different MBES systems were used during variable weather conditions resulting in grids with different resolutions.

For cruise AL447 in 2014, an EM2040c system was installed on R/V Alkor with a 200-400 kHz transducer combined with a CodaOctupus F180 motion sensor. During the 2017 AL501 cruise, a Norbit Wideband Multibeam System (iWBMS) with integrated motion sensor was operated at $400 \mathrm{kHz}$. For cruise L1905 in 2019 we used a $180 \mathrm{kHz}$ Seabeam 1000 system. More specific information on the MBES data acquisition can be found in the corresponding cruise reports (Krastel et al., 2017; Schneider von Deimling, 2014, 2019). The data were assessed, calibrated and cleaned using software packages including MBSystems, QPS Qimera/Fledermaus and Hypack/Hysweep. We acquired sound velocity profiles in regular intervals which were assigned to the data during postprocessing with respect to their time of acquisition. Tidal corrections were applied using the tidal gauge in Eckernförde with reference to NHN, DHHN92.

The final processed data have horizontal resolutions of up to $0.5 \mathrm{~m}$ and decimeter scale vertical resolutions enabling the imaging of $3-15 \mathrm{~cm}$ deep trawl marks. The backscatter amplitude data were corrected for the variation with grazing angle. We ensured the highest possible resolution by using the raw backscatter time-series data for each footprint (snippets) where available and compensated for the angle of incidence using reference grids. 


\subsection{Subbottom Profiler}

Subbottom profiler data were acquired with the R/V Alkor and R/V Elisabeth Mann Borgese in late October 2014 (cruise AL447), the beginning of July 2018 (cruise EMB187) and August 2018 (cruise AL514). We used the parametric Innomar SES-2000 medium system creating secondary peak frequencies between 4 and $15 \mathrm{kHz}$. For cruises AL447, AL514 and EMB187 we used 4, 4, and $6 \mathrm{kHz}$, respectively. The data were converted into SEG-Y format and further processed and interpreted using the IHS Markit Kingdom software packages.

\subsection{Sediment cores}

During the L1905 cruise in May 2019, we used a Frahm-Lot (100 cm core liner, diameter of $10 \mathrm{~cm}$; MBT GmbH - MacArtney Germany) to collect a total of 13 sediment cores with sediment recovery between 20 and $60 \mathrm{~cm}$.

For pore water sampling, the plastic liner was pre-drilled along the side with diameters of 2.5 and $8 \mathrm{~mm}$, respectively, then drill-holes were closed with adhesive stripes, to insert syringes or Rhizones directly after core recovery. After retrieval of sediment cores on deck, $3 \mathrm{~mL}$ of sediment were subsampled by inserting plastic syringes in a $2-4 \mathrm{~cm}$ interval into the predrilled holes. The sampled sediment from each syringe was pushed into a $20 \mathrm{~mL}$ headspace vial containing $9 \mathrm{~mL}$ of saturated $\mathrm{NaCl}$-solution (Sommer et al., 2009). Headspace vials were crimped with rubber stopper and aluminium cap and stored for gas chromatographic analysis at GEOMAR. Headspace gas $(100 \mu \mathrm{L})$ was injected into a Shimadzu gas chromatograph (GC-2014, flame ionization detector, carrier gas: He 5.0; HayeSepTM Q 80/100 column, column length: $2 \mathrm{~m}$; column diameter: 1/8''). The detection limit for $\mathrm{CH}_{4}$ was $0.1 \mathrm{ppmV}$. Precision was about $4 \%(2 \sigma)$.

Porewater was sampled onboard in 1-4 cm intervals by Rhizon extraction (Rhizosphere Research Products; e.g. Seeberg-Elverfeldt et al., 2005) for subsequent sulfate and chloride ion concentration determinations onshore. The ion concentrations were analysed at GEOMAR by using ion chromatography (Metrohm IC761; conductivity detector, eluent: $\mathrm{Na}_{2} \mathrm{CO}_{3} / \mathrm{NaHCO}_{3}$, column: Metrosep A Supp $\left.5100 / 4,0\right)$ with a precision of about $2 \%(2 \sigma)$ determined with IAPSO seawater standard. Porosity of sediment was determined from about 10-15 $\mathrm{g}$ of wet sediment samples, weighted before and after freeze-drying.

Methane solubility calculations have been performed for bottom water conditions (Water depth $=26 \mathrm{~m}$, Temperature $=15^{\circ} \mathrm{C}$, Salinity $=20(\sim 312 \mathrm{mmol} / \mathrm{l}$ chloride $)$ ) according to Yamamoto et al. (1976).

To maximise the accuracy of positioning of the vessel and the cores, we used a Stonex S9i GNSS receiver with Real Time Kinematic (RTK) corrections received from the ascos (AXIO-NET GmbH) satellite reference service resulting in centimeter-scale accuracy at the receiver. Positioning of on-board coring equipment and cable deployment resulted in meterscale accuracy for the core position (indicated by 5 -m-diameter circles in Figures 2 and 3).

\subsection{EK60}

During cruise AL447 (October, 2014) and AL514 (August, 2018) the fix mounted Kongsberg EK60 fishery echosounder was operated at multiple frequencies at 38, 70, 120, and $200 \mathrm{kHz}$ for gas bubble detection and to identify potential anomalies associated with 
submarine groundwater discharge. The four frequencies were calibrated with copper spheres in the beginning of the cruise. Pulse length and power were constant throughout the cruise.

\subsection{CTD}

During R/V Littorina Cruise L1905 we acquired three conductivity, temperature and depth (CTD) water column profiles with two towed transects using a Sea \& Sun CTD. For the transects the CTD was towed $\sim 1 \mathrm{~m}$ above the seafloor.

\section{Results}

\subsection{Bathymetry}

The high-resolution bathymetry data south of Mittelgrund show the internal morphology of the targeted pockmarks in a water depth of $\sim 25 \mathrm{~m}$ (Figure 2, Figure 3). The pockmarks show a mean elevation difference of $\sim 1.8 \mathrm{~m}$ compared to the surrounding area. They are elongated features and align around Mittelgrund, with widths of up to $200 \mathrm{~m}$ and lengths of over $1 \mathrm{~km}$. The seafloor morphology within the pockmarks is highly variable. In some areas, we observe a smooth and relatively flat seafloor, while other regions show a highly uneven surface with anomalous mounds and depressions. These depressions within the pockmarks - which we hereafter refer to as "intra-pockmarks" - mainly occur on the side furthest from Mittelgrund. The smoother areas - which we hereafter refer to as "backgroundpockmark" - mainly occur on the side closest to Mittelgrund, although patches of smoother pockmark seafloor are also observed beyond the intra-pockmarks further from Mittelgrund.

We divide the pockmark area south-west of Mittelgrund into three different regimes based on bathymetric morphology and their acoustic character. In Figure 2C we distinguish between 1) background (blue) 2) background-pockmark (black) and 3) intra-pockmark (red). The background regime describes the area outside the pockmarks (i.e. beyond both background-pockmark and intra-pockmark) which is morphologically characterized by a smooth surface with several 3 - $15 \mathrm{~cm}$ deep trawl-marks, especially to the south-east and west of the pockmark area. Within the pockmarks, the background-pockmark regime makes up most of the eastern Mittelgrund pockmark area ( $70 \%$, see Figure 2$)$ and shows a remarkably even surface. The intra-pockmark regime on the contrary shows a highly uneven surface, with depressions (intra-pockmarks) of various sizes and shapes, from circular to very complex forms. They show diameters between a couple of meters to $\sim 30 \mathrm{~m}$ with a vertical relief that ranges from decimeter scales up to $1 \mathrm{~m}$. The intra-pockmark regime shows a high pockmark density with depressions occurring close to each other without much space between them. The different regimes are in some places divided and in other places intersected and interrupted by several circular to elliptical anomalous mounded structures with heights of up to $50 \mathrm{~cm}$. The various data resolutions and data qualities of the multibeam surveys permitted a comparison of the bathymetry over the 4.5-year time period. Our visual inspection and differencing of the grids revealed no significant bathymetric changes over the course of the sampling period.

\subsection{Backscatter}

By thorough inspection of the geolocated multibeam snippet backscattering strength we found a good correlation to the morphological data (Figure 2, Figure 3). Outside the 
pockmarks, in the background regime, we generally find low backscattering strength (averaging $-36 \mathrm{~dB})$ with slightly enhanced amplitudes $(\sim-30 \mathrm{~dB})$ within the trawl marks in the south-east and west (Figure 2B). North and north-east of the pockmarks are areas of very strong backscatter that correspond to the Mittelgrund late-glacial sands.

Within the pockmarks, the background-pockmark area does not show any elevated backscatter signals $(<-30 \mathrm{~dB})$ and is characterized by a rather consistent and homogeneous response (Figure 2B). The intra-pockmark areas on the other hand, exhibit highly variable acoustic responses that vary from very strong $(<-20 \mathrm{~dB})$ to very low $(>-40 \mathrm{~dB})$ signal strength (Figure 2B). This relationship can also clearly be seen in backscatter data from the western Mittelgrund pockmark (Figure 3A). The strong backscatter values appear in patches and correlate with the bathymetric lows of the individual intra-pockmarks (Figure 3A). Nearly all individual intra-pockmarks show increased backscatter strength, with the strongest responses $(<-30 \mathrm{~dB})$ shown in white in Figure 3B. Backscatter values similar in strength to those of the late glacial sands of Mittelgrund $(\sim-20 \mathrm{~dB})$ are observed in several of the intrapockmarks.

Although the data quality from the three surveys varies due to different equipment and weather conditions, the patchy backscatter pattern of the intra-pockmarks remains obvious across all datasets.

\subsection{Subbottom profiling}

The subbottom profiler data show the characteristic shallow gas front of Eckernförde Bay with the acoustic turbidity zone below (Figure 4) as observed by Hinz et al. (1971). The depth beneath the seafloor of the free gas front varies significantly over time. During the early July 2018 measurement campaign, the average depth of free gas in the background regime was $\sim 70 \mathrm{~cm}$ while in October 2014 gas occurrences at a depth of $\sim 40 \mathrm{~cm}$ were observed, in accordance with reports by Wever et al. (1998). In July 2018 (Figure 4A), the acoustic manifestations of shallow gas accumulations in the background regime appear as condensed regions of high reflectivity with sharply delineated tops. In October 2014 (Figure 4B), by contrast, where the gas accumulations occur closer to the seafloor, they have a less condensed and more distributed acoustic manifestation. In the intra-pockmark regime, we observe similar changes over time, although they do not seem to be as pronounced as the temporal changes observed outside of the pockmarks (in the background regime). High amplitude reflections occur in the uppermost $50 \mathrm{~cm}$ throughout the datasets in the intrapockmark regime.

Outside of the pockmarks, in the background area, the free gas manifestation shows strong horizontally continuous amplitudes with occasional regions where the gas front is absent or occurs at greater depths (Figure 4), previously described by Albert et al. (1998) as acoustic windows. Within the pockmarks, free gas appears closer to the seafloor but the gas front is less continuous and the reflected acoustic energy is more distributed over a wider depth interval (Figure 4, Figure 5). Several patches, indicating free gas, occur close to the seafloor.

We extracted the reflected acoustic energy within a $50 \mathrm{~cm}$ window below the seafloor by computing the envelope of each trace and subsequently summing the envelope within that window (Figure 4, Figure 5). The sum of energy shows strongly elevated energy levels at shallow sub-seafloor depths within the intra-pockmark regime compared to the backgroundpockmark and background regimes. 
The background-pockmark area, delineated in grey in Figure 5, shows a very weak seafloor reflection and no internal reflections above a layered high amplitude southward dipping unit. This unit extends from the surface of Mittelgrund in the north beneath the pockmarks and is commonly referred to as the late glacial sands (Jensen et al., 2002). High energies in the $50 \mathrm{~cm}$ below the seafloor are observed in the north of the profile shown in Figure 5 around Mittelgrund, where the late glacial sands crop out at the seafloor and create a rough and hummocky morphology. This late glacial sand unit is only visible in the northern part of the pockmark area (in the background-pockmark regime). Distal from Mittelgrund, in the intra-pockmark regime, free gas occurs close to the seafloor, limiting the acoustic penetration. The transparent unit above the late glacial sands in the background-pockmark region shows no signs of free gas and low to moderate reflection energy in the subbottom profiler as well as in the backscatter data.

\subsection{Sediment cores}

We obtained sediment cores, $20-60 \mathrm{~cm}$ in length, from all three acoustically distinguishable regimes (Figure 2, 3 and 6). All sediment cores consisted of a dark-grey to black muddy lithology with a variable cm-scale brown fluffy layer on top. The water content of the mud throughout the cores was extremely high, with porosities averaging $93 \%$ in the upper centimeters as previously reported by Silva and Brandes (1998). More than $50 \%$ of the attempts to recover a sediment core on deck failed due to discharge of the soft, unconsolidated, weak and water saturated mud, resulting in loss of the core before sampling could take place.

Porewater geochemistry profiles, i.e. methane-, chloride-, and sulfate-concentration versus depth from these cores are shown in Figure 6. No distinct differences in porosity or other sediment properties were observed in the cores. The background core (FL19, Figure 1, 5 and 6) shows no enhanced methane concentrations in the uppermost $30 \mathrm{~cm}$ and an increase of methane to $\sim 2 \mathrm{mM}$ below $50 \mathrm{~cm}$. Sulfate in the core decreases between sediment surface and $30 \mathrm{~cm}$ depth (Sulfate Methane Transition Zone, SMTZ) from about $16 \mathrm{mM}$ down to below $\sim 2 \mathrm{mM}$, while the chloride concentration in the porewater is more or less constant with depth at about 290-320 $\mathrm{mM}$.

The cores collected in the background-pockmark area show a higher SMTZ located at about $10 \mathrm{~cm}$ below sediment surface; however, maximum methane concentrations below this depth are about $1 \mathrm{mM}$, which is well below the methane solubility at this depth (i.e. 5.18-5.27 $\mathrm{mM}$; Figure 6). No free gas voids were observed in the background and backgroundpockmark sediment after core recovery on deck. Core FL17 in the background-pockmark regime shows one of the strongest gradients in sulfate decrease, while core FL44 displays one of the lowest. Chlorinity profiles vary in the background-pockmark area. While the northernmost core FL17 shows a strong decrease with depth to $\sim 5 \mathrm{mM}$ of chloride, the southernmost core FL44 shows chloride variability similar to the background core FL19.

With core FL24 we targeted one of the mound structures where only minor porewater freshening with depth is observed. The sulfate and methane concentration profiles of FL24 are comparable to background core FL19 (Figure 6).

In the intra-pockmark regime, all cores show a strong groundwater influence from below. Porewater chloride concentrations of less than $100 \mathrm{mM}(\sim 30 \%$ of the bottom water concentration) were measured at about $10 \mathrm{~cm}$ (Figure 6). These low chloride values are accompanied by high methane concentrations of up to $2 \mathrm{mM}$ at $10 \mathrm{~cm}$ and strong methane concentration gradients with depth. The SMTZ occurs between $\sim 5-15 \mathrm{~cm}$ in the intra- 
pockmark regime and methane concentrations of up to $5.42 \mathrm{mM}$ were measured in core FL18 at about $30 \mathrm{~cm}$ (Figure 6). As bubble formation even under in situ pressure conditions is anticipated based on the measured methane concentration, the scattered methane concentration measured below $30 \mathrm{~cm}$ is probably related to strong degassing effects on deck. Indeed, several cores from this region showed evidence of free gas bubbles beneath $\sim 10 \mathrm{~cm}$, when they came to the surface (Figure 7). This includes core FL42, which for an unknown reason, does not show enhanced dissolved $\mathrm{CH}_{4}$ porewater concentrations higher than 0.3 $\mathrm{mM}$. We attribute this lack of methane to degassing during core acquisition and unfortunately too long storage time on deck until sampling (Abegg \& Anderson, 1997; Wever et al., 1998).

\subsection{CTD}

We conducted three CTD casts with two towed transects in different regions of Eckernförde Bay. The location of the towed CTD transect is shown in Figure 1A. All of the casts and transects show low saline surface water of $S \sim 14$ ( $218 \mathrm{mmol} / \mathrm{l}$ chloride) with an increasing salinity to $\sim 20(\sim 312 \mathrm{mmol} / \mathrm{l}$ chloride $)$ in the bottom water, as characteristic for the Baltic Sea (Bange et al., 2011; Lennartz et al., 2014). Although we managed to tow the CTD as close as $\sim 1 \mathrm{~m}$ above the seafloor, none of the CTD casts or transects showed any groundwater influence on the water-column, neither within nor outside of the pockmarks.

\section{Discussion}

\subsection{Characterisation of Eckernförde Bay pockmarks}

Albert et al. (1998) have noted that pockmarks closer to the coast of Eckernförde Bay appear to be a different type altogether than those around Mittelgrund. This was based on the observation of low methane and low chloride concentrations, as measured by Whiticar and Werner (1981) and later by Whiticar (2002) in the Mittelgrund pockmarks, compared to high methane concentrations in pockmarks closer to the coast.

Our high frequency multibeam approach enabled us to collect targeted sediment cores with a meter-scale accuracy. This new data suggest a classification of the pockmarks into different regimes rather than separating the coastal and Mittelgrund pockmarks into different types based on different eroding agents from below. Depending on core location, even within the same pockmark, methane and chloride concentrations can vary significantly (Figure 6). While the background regime shows no influence of groundwater, a comparatively deep SMTZ and only a moderate positive methane gradient below the SMTZ, the cores from within the pockmarks are variable. In the northern background-pockmark regime low methane concentrations correlate with a thin organic-rich Littorina mud cover above the late glacial sands (Figure 5). The subbottom profiler data show no signs of free gas or internal reflections in this area. We observe a moderate methane concentration gradient below the SMTZ with maximum methane concentrations well below the solubility of methane in porewater (core FL17, Figure 6). The even seafloor of the background-pockmark area therefore corresponds to high groundwater influence with low methane concentrations. The background-pockmark sulfate profile of core 44 shows anomalously high concentrations of sulfate compared to the other cores, down to $12 \mathrm{~cm}$. The high sulfate is accompanied by moderate methane concentrations and high chloride concentrations indicating limited groundwater influence. The sigmoidal shape of the sulfate concentration profile below $12 \mathrm{~cm}$ indicates a non-steady state of anaerobic microbial methane oxidation (AOM) related to 
sulfate reduction during the respective season (Schulz, 2006). Although the porosity of this core is not anomalous compared to other cores, a high permeability and effective exchange of porewater with bottom water at the top of the core could be the cause. The backgroundpockmark regime therefore varies in sulfate and chloride according to the location of the core, the thickness of the Littorina mud cover and the influence of ascending groundwater.

In the intra-pockmark regime, the mud reaches thicknesses of more than $1 \mathrm{~m}$ above the late-glacial sands and the SMTZ is shifted to shallower depths compared to the background-pockmark. Free gas occurs very close to the seafloor as seen in the subbottom profiler data as well as in the sediment cores and the elevated methane concentrations are reaching oversaturation at depth (e.g. FL27, Figure 6). Although Jensen et al. (2002) reported that the late glacial sands extend over the entire Eckernförde basin, we cannot resolve this southward dipping unit outside the background-pockmark area due to the acoustic turbidity where free gas is present. All the cores in this morphologically rough intra-pockmark region show a strong groundwater influence with high methane concentrations and a shallow SMTZ.

\subsection{Formation and modification processes of the intra-pockmarks}

The formation of the Eckernförde pockmarks has been debated for decades. Bottom currents (Werner, 1978), military activities (Edgerton et al., 1966), gas seepage (Fabian \& Roese, 1962) and groundwater seepage (Khandriche \& Werner, 1995; Whiticar \& Werner, 1981) have all been proposed as formation mechanisms since their discovery by Edgerton et al. (1966). It is now widely accepted that episodic artesian groundwater springs, in combination with bottom currents, erode the pockmarks (Bussmann \& Suess, 1998; Jensen et al., 2002; Kaleris et al., 2002; Müller et al., 2011; Patiris et al., 2018; Schlüter et al., 2004; Whiticar, 2002). The newly observed (this study) eyed intra-pockmarks in Eckernförde Bay seem to host both high methane and low chloride concentrations. Albert et al. (1998) proposed that the Eckernförde pockmarks act as morphological sinks for organic material and therefore could enhance methanogenesis close to the sediment-water interface. Khandriche and Werner (1995) suggested that the erosion of the pockmarks, once initiated, leads to a positive feedback mechanism since deeper sediment layers with a higher gas content are exposed to water currents. Since the depth of the gas front varies within the sediments by tens of centimeters (magnitudes higher than accumulation or erosion rates) due to seasonal variations and short-term weather conditions, we assume that the high gas content close to the seafloor within the pockmarks is the result of groundwater seepage rather than erosion. The high gas content combined with the low chlorinity very close to the seafloor induce sediment instabilities and a reduction in shear strength (Sills \& Wheeler, 1992) which consequently make sediments more easily erodible. In areas where only minor gas concentrations were measured in the pockmarks (background-pockmark area) we find an even and flat seafloor morphology, whereas in areas with strong methane gradients (intra-pockmark area) we observe a scoured surface which likely indicates lower shear strength and additional erosion. Since we did not observe any indications for seafloor scouring by bottom currents (e.g. elongation, preferred orientation, azimuthal variations in slope of the intra-pockmarks) we propose that the abnormally shallow gas (which forms due to SGD, see Section 5.3.) and the episodic release of groundwater are the main drivers of intra-pockmark formation. We suggest that the free gas changes the geotechnical properties, i.e. reduces the shear strength (Sills \& Wheeler, 1992), meaning that even weak groundwater discharge phases erode the very fine sediments. The background pockmark, on the other hand, shows no indications for elevated methane concentrations and we therefore presume that its morphology is the sole result of groundwater discharge during strong discharge phases. 


\subsection{Enhanced backscatter signals of intra-pockmarks}

High backscatter at the bottom of pockmarks, as we observed in Eckernförde Bays intra-pockmarks, is a common phenomenon (Dandapath et al., 2010; Hovland et al., 2002; Judd \& Hovland, 2009; Loncke et al., 2004). Seeping fluids frequently result in authigenic carbonate precipitation due to the microbially driven anaerobic oxidation of methane once methane enters the sulfate-methane transition zone (e.g. Boetius et al., 2000; Ritger et al., 1987). These carbonates are often associated with high-amplitude, positive-polarity reflections and a high backscatter signal in pockmarks (Böttner et al., 2019; Dandapath et al., 2010; Ho et al., 2012; Judd \& Hovland, 2009). Similarly, the suspension of fine-grained material due to fluid escape, leaving the coarser-grained material behind as well as enhancing biological activity due to seeping fluids (skeleton remains, dead and living shells, etc.) can create a strong impedance contrast and a rougher surface area and therefore result in strong backscatter values in pockmarks (Hovland, 1989; Hovland et al., 2002; Reusch et al., 2015). These pockmarks containing highly reflective objects at their centres have commonly been described as 'eyed' pockmarks (Hovland et al., 2002).

In Eckernförde Bay, the carbonate concentration in the sediment is extremely low $(<2 \%)$ due to undersaturation in bottom waters (Lewy, 1975; Wefer et al., 1987), ruling out carbonate precipitation as a plausible cause of high backscatter. Also, the pockmark area, which was well sampled over recent decades, shows a surface sedimentary composition that consists of homogeneous Holocene mud without a significant amount of coarser-grained material (Section 4.4., Jensen et al., 2002; Martens et al., 1999; Schlüter et al., 2004; Whiticar, 2002). Similar to carbonate, gas bearing sediments induce a strong impedance contrast to the surrounding water-saturated sediments which creates a strong (albeit negative polarity) reflection. Beneath the intra-pockmarks, the closely spaced subbottom profiler data show that the shallow gas front occurs closer to the seafloor and becomes patchier compared to the surrounding regions. This is highlighted by the sum of acoustic energy extracted within a $50 \mathrm{~cm}$ window beneath the seafloor (Figure 4). The upper $50 \mathrm{~cm}$ includes the strong reflections associated with the shallow gas in the intra pockmark regime (see $\mathrm{CH}_{4}$ saturation in Figure 6) while excluding the reflections associated with deeper gas in the background. Additionally, the sediment cores collected within the intra-pockmarks show elevated methane concentrations compared to the background-pockmark and background cores. In several sediment cores recovered on deck, we visually detected free gas bubbles $\sim 10 \mathrm{~cm}$ beneath the sediment-water interface (Figure 7). Moreover, measured methane concentrations of the intra-pockmark regime are comparable to the solubility limit of methane at in situ pressure, temperature and salinity conditions (Figure 6). This, together with the good correlation of multibeam backscatter strength and subbottom profiler reflectivity shown in Figure 4 and Figure 5, suggests that the elevated backscatter results from free shallow gas within the sediment at depth of $\sim 10-20 \mathrm{~cm}$.

Tang et al. (1994) reported that backscatter from a $40 \mathrm{kHz}$ benthic acoustic measurement system results from gas voids about $1 \mathrm{~m}$ beneath the seafloor in Eckernförde Bay. In a geologically very similar environment to Eckernförde Bay, Schneider von Deimling et al. (2013) showed how a $12 \mathrm{kHz}$ multibeam system can be used to map shallow gas in up to $12 \mathrm{~m}$ sediments depth, while a $95 \mathrm{kHz}$ system detected the sediment-water interface. Our results indicate that, in the soft muddy sediments of Eckernförde Bay (with low attenuation coefficients of $\sim 0.1-0.2 \mathrm{~dB} \mathrm{~m}^{-1} \mathrm{kHz}^{-1}$ (Jackson \& Richardson, 2007)), even the $400 \mathrm{kHz}$ systems penetrate the upper few decimetres of the seafloor and volume scattering provides information on subsurface sediment properties (in this case, partially gas saturated sediment). A large-scale seafloor backscatter classification approach in Eckernförde Bay by Alevizos et al. (2018) classified parts of the Mittelgrund pockmarks to consist of sand with small 
amounts of gravel due to the elevated backscatter signals in the pockmarks. The intrapockmarks indeed exhibit exceptionally high backscatter values with signal strengths comparable to the backscatter of the late-glacial sands of Mittelgrund. However, no substantial amount of sands or gravels have been reported from sediment cores or grabs in this region and the automated seafloor classification likely incorrectly identified the free gas as sand.

The depth of the shallow gas front in Eckernförde Bay changes over time on a short term (effective pressure dependant) and seasonal (water temperature dependant) basis (Treude et al., 2005; Wever et al., 1998, 2006). On a seasonal basis, the bottom-waters have highest temperatures around October-November with lowest bottom-water temperatures during March-April (Lennartz et al., 2014). While a decrease in water temperature increases the solubility of methane, a temperature increase reduces the solubility and therefore increases the amount of free gas bubbles. The free gas front is therefore expected to be deepest during March-April and shallowest between October-November (Wever et al., 1998). We observe this phenomenon in our subbottom data where the EMB187 line (acquired on 7th July 2018) shows a free gas front around $70 \mathrm{~cm}$ below the seafloor in the background area compared to $\sim 40 \mathrm{~cm}$ below the seafloor in the AL447 data (acquired on 22nd October 2014).

Although the different multibeam systems used for acquisition were not calibrated for the target strength (i.e., pockmark backscatter cannot be directly compared) the backscatter distribution pattern of the intra-pockmarks seem to be unaffected by seasonal variations and show the same strong patchy backscatter character throughout all three datasets (22nd October, 8th September, 16th May). This suggests that free shallow gas constantly resides in the uppermost decimetres within the intra-pockmark regime and affects multibeam backscatter systems with 180,300 , and $400 \mathrm{kHz}$ to a similar degree. This is supported by strong amplitudes close to the seafloor-water interface in all subbottom profiler data (Figure 4). We suggest that this phenomenon results mainly from the ascending groundwater, which is thought to intensify the upward migration of dissolved as well as free methane gas (Khandriche \& Werner, 1995), thereby increasing gas concentrations closer to the seafloor. Moreover, as sulfate is rapidly depleted in porewater by ascending groundwater (Figure 6), the SMTZ is uplifted and thus the depths where methanogenesis would lead to oversaturation. Therefore, gas bubble formation is uplifted in areas of SGD.

\subsection{Acoustic indicators for groundwater}

One aim of this study was to find hydroacoustic indications for SGD in the water column or the seafloor. Khandriche and Werner (1995), as well as Bussmann \& Suess (1998) reported decreased salinities in the water column down to $S=2.9(\sim 45 \mathrm{mmol} / \mathrm{l}$ chloride) near the bottom of a pockmark, indicating a strong groundwater outflow during their surveying. However, repeated dedicated water column analysis of multibeam water column imaging data and Simrad EK60 singlebeam data over several years revealed no indications of groundwater influence on the water-column above the pockmark sites. We could observe several small gas seeps and single gas bubbles in the acoustic water column data though (Figure A1). Horizontal, locally continuous pycnoclines observed in the EK60 data do not seem to be affected by fluid seepage above the pockmarks (Figure A1). This agrees with findings from Bussmann and Suess (1998) who reported that the water column stability was not affected by less dense groundwater at the base of the pockmarks. The lack of observed acoustic reflections from discharging groundwater may indicate a quiescence phase during our sampling periods. Our sediment porewater chloride profiles (collected May 2019) but also published chloride records from Albert et al., (1998), Bussmann et al. (1999), Müller et al. (2011) or Schlüter et al. (2004) indicate that mixing of low saline groundwater with seawater 
already occurs in the upper sediments preventing the low saline groundwater from seeping out. In Eckernförde Bay the discharge rate is highly variable since groundwater discharges episodically (Bussmann \& Suess, 1998; Schlüter et al., 2004). Unfortunately, no long-term seepage meters were available during our surveys. Even during a strong groundwater outflow event, like observed by Khandriche and Werner (1995) or (Bussmann \& Suess, 1998), strong mixing between fresh and saltwater could occur, resulting in a gradual transition of acoustic impedances between the two water bodies which prevents the development of a reflection at their interface. We therefore used a different attempt to find acoustic indications for SGD by analysing the seafloor morphology and backscatter characteristics.

In general, the sediment cores we collected in Eckernförde Bay show a strong relation between methane concentrations and groundwater. Only in core FL17, low chloride porewaters occur close to the sediment surface but no enhanced methane concentrations were observed, nor do we find acoustic indications for free gas in the background-pockmark area. We attribute this to the relatively thin organic-rich sediment cover above the late glacial sands of Mittelgrund which are dipping south beneath the pockmark (Figure 5). The thickness of organic-rich Littorina mud covering the sands increases with distance from Mittelgrund, and once the Littorina mud reaches thicknesses of more than $\sim 1 \mathrm{~m}$, free gas occurs in the sediments.

With this one exception, all porewater profiles show increased methane concentrations where chloride concentrations are low. In previous studies, Bugna et al. (1996) and Dulaiova et al. (2010) used elevated methane concentrations in groundwater as a tracer for SGD. Ascending groundwater is not only often already enriched in dissolved methane but also suppresses sulfate mixing into the sediment and therefore increases the amount of metabolizable organic carbon reaching the methanogenic zone, allowing gas to form closer to the seafloor (Albert et al., 1998; Dulaiova et al., 2010). Albert et al. (1998) modelled the influence of different groundwater fluxes on methane concentrations in Eckernförde Bay and showed how an increased groundwater flux can lead to enhanced methane concentrations close to the seafloor when assuming a higher input of metabolizable organic material into morphological sinks like pockmarks. As discussed earlier we acoustically detected and highly accurately located the free gas phase in the muddy sediments of Eckernförde Bay. The free gas phase and therefore the high backscatter in the pockmarks directly correlates with low chloride concentrations. We therefore assume that in areas with sufficient organic material and methanogenesis, acoustic investigations can provide indications for groundwater seepage. Since Fleischer et al. (2001) showed how globally abundant gaseous muds are in coastal waters and shallow adjacent seas, our approach will have significant implications for future efforts to detect and characterise SGD.

\section{Conclusions}

Using high-resolution acoustic data in combination with 13 precisely located sediment cores we reveal the nature of different pockmark classifications made by previous authors in Eckernförde Bay. We propose a classification of the pockmarks into different regimes according to their morphological and backscatter characteristics rather than differentiating them into different types based exclusively on the porewater geochemistry. We discovered a new form of eyed intra-pockmarks with enhanced backscatter signals at their bases which is neither caused by authigenic carbonates nor by a change in seafloor material, but rather by shallow gas occurring close to the seafloor. This implies that even when using high frequencies, significant signal penetration and volume scattering need to be considered and seabed classification methods must take this into account. We assume that submarine groundwater discharge 1) enhances upward migration of dissolved and free methane gas 
bubbles to the seafloor, and 2) enhances methanogenesis close to the seafloor due to decreased sulfate concentrations in groundwater. This leads to an extremely shallow, consistent and more stable gas front within the intra-pockmarks, less affected by temperature changes than the surrounding area. We suggest that this consistent shallow gas alters the geotechnical properties of the unconsolidated sediments making them more easily erodible by the discharging groundwater than the surrounding sediments. The intra-pockmarks are therefore a manifestation of groundwater flow that mobilises free gas, which in turn promotes sediment weaknesses and subsequent erosion. Recognizing this process is important for understanding how pockmarks can be caused by SGD and why they occur where they do. Ultimately, this will help in identifying and characterising offshore groundwater systems which may become important sources of fresh water in the future.

We showed that high-frequency multibeam data can be used to detect shallow gas within the sediment in regions of SGD. The seafloor morphology combined with backscatter data can, therefore, be used to obtain indications for potential groundwater seepage in organic-rich, gaseous, and muddy sediments. Since shallow gas in muddy sediments is a common global phenomenon, our study highlights the importance of investigating how SGD and shallow gas interact close to the seafloor. We showcase that even at $400 \mathrm{kHz}$ frequency, backscattering strength is significantly increased by subsurface volume scattering from shallow gas. Our study also highlights the potential for shallow gas to confuse bathymetric depth and backscatter interpretations, in addition to studies dealing with lower frequencies (e.g. Gaida et al., 2019; Schneider von Deimling et al., 2013). In particular, we show that high-resolution hydroacoustic surveys followed by targeted coring can be used to identify specific locations of SGD and provide new insight into how SGD influences seafloor geochemistry and morphology. Our knowledge on the occurrence of SGD in deeper basins and oceans is limited (Post et al., 2013) because of the lack of suitable detection techniques. The methodology we presented describes a possible way to survey SGD associated with methane release and can be used elsewhere around the world to improve the identification and characterisation of SGD.

\section{Acknowledgements}

We are thankful for onboard coring and sediment sampling assistance by M. Ippach. Laboratory chemical analyses were conducted by A. Bodenbinder, A. Bleyer, and B. Domeyer. Thanks also to Ercan Erkul and the crew of the RV Littorina, RV Alkor, and RV Elisabeth Mann Borgese for their help and support during data acquisition. Hoffmannthanks the marine geophysics and hydroacoustics working group of the University of Kiel for their sustained support. Access to the porewater geochemistry, subbottom profiler, and MBES data is available through Pangaea data repository (https://doi.pangaea.de/10.1594/PANGAEA.912274). This work resulted from the BONUS ECOMAP and BONUS SEAMOUNT projects, supported by BONUS (art. 185), funded jointly by the EU and the Federal Ministry of Education and Research of Germany (BMBF, grant no. 03F0771B), the National Centre for Research and Development of Poland (NCBR), and the Innovation Fund Denmark (Innovationsfonden). Additional funding was provided by New Zealand's Ministry of Business, Innovation and Employment (MBIE) as part of the GNS Science-led programme "Understanding petroleum source rocks, fluids, and plumbing systems in New Zealand basins: a critical basis for future oil and gas discoveries" (Contract C05X1507). We gratefully acknowledge the German Academic Exchange Service (DAAD) for providing a Short-Term research grant to Hoffmann (Funding program number: 57440917). Data processing and analysis were undertaken through academic licences for 
QPS Qimera, Fledermaus, and IHS Markit's Kingdom software. Hoffmann is supported by a University of Otago PhD scholarship.

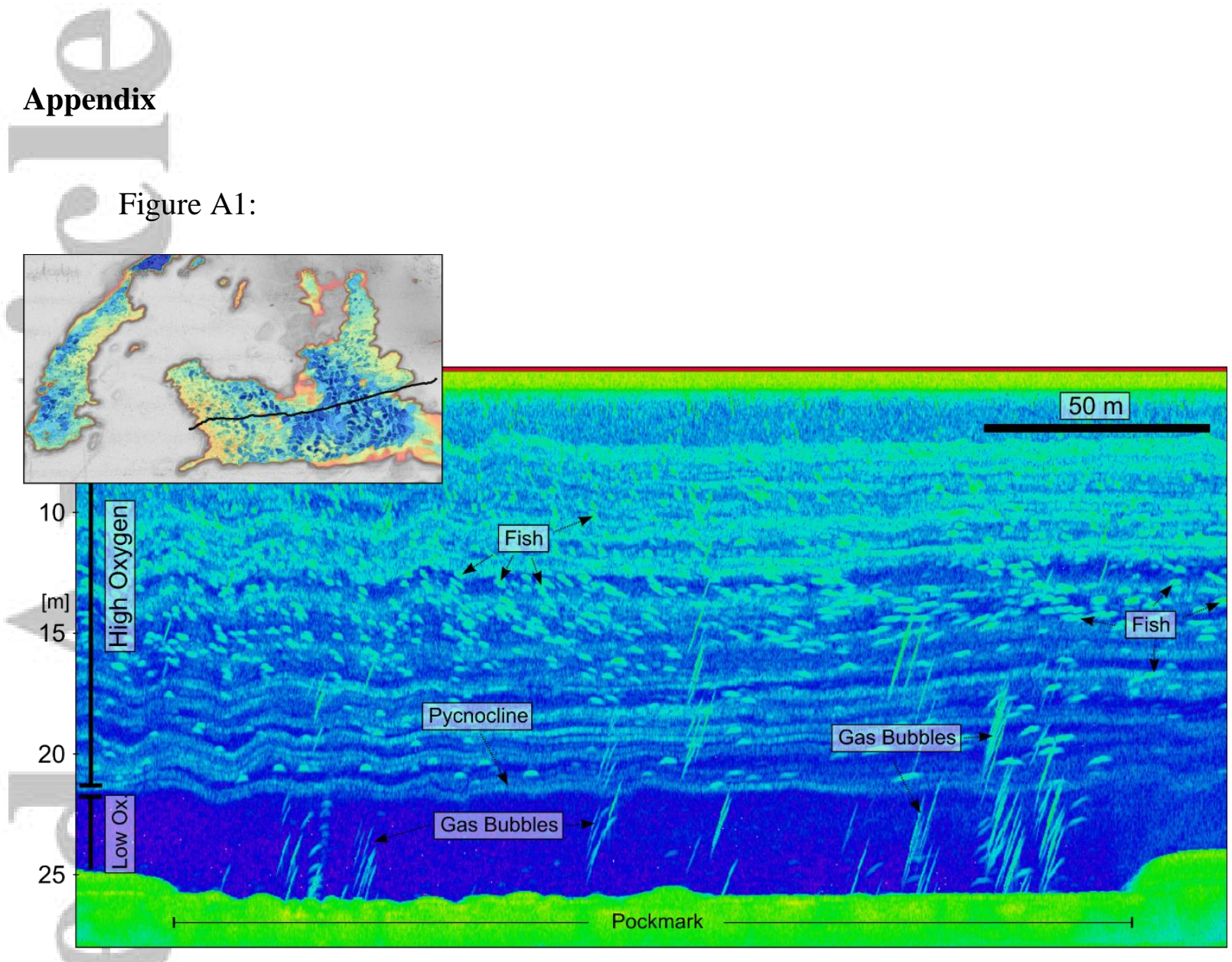

Figure A1: EK60 single beam operated at $70 \mathrm{kHz}$ across a pockmark. Pycnoclines, fish and gas bubbles are highlighted.

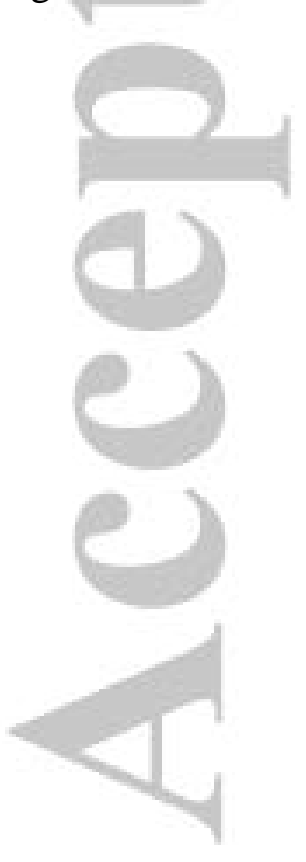




\section{References}

Abegg, F., \& Anderson, A. L. (1997). The acoustic turbid layer in muddy sediments of Eckernfoerde Bay, Western Baltic: Methane concentration, saturation and bubble characteristics. Marine Geology, 137(1-2), 137-147. https://doi.org/10.1016/S00253227(96)00084-9

Albert, D. B., Martens, C. S., \& Alperin, M. J. (1998). Biogeochemical processes controlling methane in gassy coastal sediments-Part 2: groundwater flow control of acoustic turbidity in Eckernförde Bay Sediments. Continental Shelf Research, 18, 1771-1793.

Alevizos, E., Snellen, M., Simons, D., Siemes, K., \& Greinert, J. (2018). Multi-angle backscatter classification and sub-bottom profiling for improved seafloor characterization. Marine Geophysical Research, 39(1-2), 289-306. https://doi.org/10.1007/s11001-017-9325-4

Balzer, W. (1984). Organic matter degradation and biogenic element cycling in a nearshore sediment (Kiel Bight) 1. Limnology and Oceanography, 29(6), 1231-1246.

Balzer, W., Erlenkeuser, H., Hartmann, M., Müller, P. J., \& Pollehne, F. (1987). Diagenesis and exchange processes at the benthic boundary. In Seawater-sediment interactions in coastal waters (pp. 111-161). Springer.

Bange, H. W., Hansen, H. P., Malien, F., Laß, K., Dale, A. W., Karstensen, J., et al. (2011). Boknis Eck time series station (SW Baltic Sea): measurements from 1957 to 2010. LOICZ Inprint, 2011(1), 16-22.

Berndt, C. (2005). Focused fluid flow in passive continental margins. Philosophical Transactions of the Royal Society A: Mathematical, Physical and Engineering Sciences, 363(1837), 2855-2871. https://doi.org/10.1098/rsta.2005.1666

Berndt, C., \& Micallef, A. (2019). Could offshore groundwater rescue coastal cities? Nature, 574(7776), 36.

Biastoch, A., Treude, T., Rüpke, L. H., Riebesell, U., Roth, C., Burwicz, E. B., et al. (2011). Rising Arctic Ocean temperatures cause gas hydrate destabilization and ocean acidification. Geophysical Research Letters, 38(8), n/a-n/a. https://doi.org/10.1029/2011GL047222

Boetius, A., Ravenschlag, K., Schubert, C. J., Rickert, D., Widdel, F., Gieseke, A., et al. (2000). A marine microbial consortium apparently mediating anaerobic oxidation of methane. Nature, 407(6804), 623-626. https://doi.org/10.1038/35036572

Borges, A. V, Champenois, W., Gypens, N., Delille, B., \& Harlay, J. (2016). Massive marine methane emissions from near-shore shallow coastal areas. Scientific Reports, 6, 27908.

Böttner, C., Berndt, C., Reinardy, B. T. I., Geersen, J., Karstens, J., Bull, J. M., et al. (2019). Pockmarks in the Witch Ground Basin, Central North Sea. Geochemistry, Geophysics, Geosystems, 20(4), 1698-1719. https://doi.org/10.1029/2018GC008068

Bugna, G. C., Chanton, J. P., Cable, J. E., Burnett, W. C., \& Cable, P. H. (1996). The importance of groundwater discharge to the methane budgets of nearshore and continental shelf waters of the northeastern Gulf of Mexico. Geochimica et Cosmochimica Acta, 60(23), 4735-4746. https://doi.org/10.1016/S0016-7037(96)002906

Burnett, W. C., \& Dulaiova, H. (2003). Estimating the dynamics of groundwater input into the coastal zone via continuous radon-222 measurements. Journal of Environmental 
Radioactivity, 69(1-2), 21-35. https://doi.org/10.1016/S0265-931X(03)00084-5

Burnett, W. C., Aggarwal, P. K., Aureli, A., Bokuniewicz, H., Cable, J. E., Charette, M. A., et al. (2006). Quantifying submarine groundwater discharge in the coastal zone via multiple methods. Science of The Total Environment, 367(2-3), 498-543. https://doi.org/10.1016/j.scitotenv.2006.05.009

Bussmann, I., \& Suess, E. (1998). Groundwater seepage in Eckernförde Bay (Western Baltic Sea): Effect on methane and salinity distribution of the water column. Continental Shelf Research, 18(14-15), 1795-1806. https://doi.org/10.1016/S0278-4343(98)00058-2

Bussmann, I., Dando, P., Niven, S., \& Suess, E. (1999). Groundwater seepage in the marine environment:role for mass flux and bacterial activity. Marine Ecology Progress Series, 178(1), 169-177. https://doi.org/10.3354/meps178169

Cable, J. E., Burnett, W. C., \& Chanton, J. P. (1997). Magnitude and variations of groundwater seepage along a Florida marine shoreline. Biogeochemistry, 38(2), 189205.

Cayocca, F., Sultan, N., Cochonat, P., \& Bourillet, J. F. (2001). Evaluation of the risk of marine slope instability: A pseudo-3d approach for application to large areas. Marine Georesources and Geotechnology, 19(2), 107-133. https://doi.org/10.1080/10641190109353807

Chapron, E., Van Rensbergen, P., De Batist, M., Beck, C., \& Henriet, J. P. (2004). Fluidescape features as a precursor of a large sublacustrine sediment slide in Lake Le Bourget, NW Alps, France. Terra Nova, 16(5), 305-311. https://doi.org/10.1111/j.13653121.2004.00566.x

Cho, H.-M., Kim, G., Kwon, E. Y., Moosdorf, N., Garcia-Orellana, J., \& Santos, I. R. (2018). Radium tracing nutrient inputs through submarine groundwater discharge in the global ocean. Scientific Reports, 8(1), 2439. https://doi.org/10.1038/s41598-018-20806-2

Dandapath, S., Chakraborty, B., Karisiddaiah, S. M., Menezes, A., Ranade, G., Fernandes, W., et al. (2010). Morphology of pockmarks along the western continental margin of India: Employing multibeam bathymetry and backscatter data. Marine and Petroleum Geology, 27(10), 2107-2117. https://doi.org/10.1016/j.marpetgeo.2010.09.005

Dietrich, G. (1951). Oberflächenströmungen im Kattegat, im Sund und in der Beltsee. Deutsche Hydrografische Zeitschrift, 4(4-6), 129-150.

Dulaiova, H., Camilli, R., Henderson, P. B., \& Charette, M. A. (2010). Coupled radon, methane and nitrate sensors for large-scale assessment of groundwater discharge and non-point source pollution to coastal waters. Journal of Environmental Radioactivity, 101(7), 553-563. https://doi.org/10.1016/j.jenvrad.2009.12.004

Edgerton, H. E., Seibold, E., Vollbrecht, K., \& Werner, F. (1966). Morphologische Untersuchungen am Mittelgrund (Eckernförde Bucht, westliche Ostsee). Meyniana, 16, $37-50$.

Fabian, H. S., \& Roese, K. L. (1962). Das Erdölfeld Schwedeneck. Erdöl-Zeitschrift, 78, 283-294.

Gaida, T. C., Mohammadloo, T. H., Snellen, M., \& Simons, D. G. (2019). Mapping the Seabed and Shallow Subsurface with Multi-Frequency Multibeam Echosounders. Remote Sensing, 12(1), 52. https://doi.org/10.3390/rs12010052

Geyer, D. (1964). Eigenschwingungen und Erneuerung des Wasser in der Eckernförder Bucht 
unter besonderer Berücksichtigung der Sturmlage vom 5.-6. Dezember 1961. Kieler Meeresforschung, 21, 33-54.

Goff, J. A. (2019). Modern and Fossil Pockmarks in the New England Mud Patch: Implications for Submarine Groundwater Discharge on the Middle Shelf. Geophysical Research Letters, 46(21), 12213-12220. https://doi.org/10.1029/2019GL084881

Gustafson, C., Key, K., \& Evans, R. L. (2019). Aquifer systems extending far offshore on the U.S. Atlantic margin. Scientific Reports, 9(1). https://doi.org/10.1038/s41598-01944611-7

Healy, T., \& Wefer, G. (1980). The efficacy of submarine abrasion vs. cliff retreat as a supplier of marine sediment in the Kieler Bucht, Western Baltic. Meyniana, 32, 89-96.

Healy, T., \& Werner, F. (1987). Sediment budget for a semi-enclosed sea in a nearhomogeneous lithology; example of Kieler Bucht, western Baltic. Senckenbergiana Maritima, 19(3-4), 195-222.

Hillman, J. I. T., Gorman, A. R., \& Pecher, I. A. (2015). Geostatistical analysis of seafloor depressions on the southeast margin of New Zealand's South Island - Investigating the impact of dynamic near seafloor processes on geomorphology. Marine Geology, 360, 70-83. https://doi.org/10.1016/j.margeo.2014.11.016

Hinz, K., Kögler, F. C., Richter, I., \& Seibold, E. (1971). Reflexionsseismische Untersuchungen mit einer pneumatischen Schallquelle und einem Sedimentecholot in der westlichen Ostsee. Meyniana, 21, 17-24.

Ho, S., Cartwright, J. A., \& Imbert, P. (2012). Vertical evolution of fluid venting structures in relation to gas flux, in the Neogene-Quaternary of the Lower Congo Basin, Offshore Angola. Marine Geology, 332-334, 40-55. https://doi.org/10.1016/j.margeo.2012.08.011

Hovland, M. (1989). The formation of pockmarks and their potential influence on offshore construction. Quaterly Journal of Engineering Geology, 22, 131-138.

Hovland, M., Gardner, J. V, \& Judd, A. G. (2002). The significance of pockmarks to understanding fluid flow processes and geohazards. Geofluids, 2, 127-136.

IPCC. (2014). Climate Change 2014: Synthesis Report. Contribution of Working Groups I, II and III to the Fifth Assessment Report of the Intergovernmental Panel on Climate Change [Core Writing Team, R.K. Pachauri and L.A. Meyer (eds.)]. IPCC, Geneva, Switzerland, 151.

Jackson, D., \& Richardson, M. (2007). High-frequency seafloor acoustics. Springer Science $\&$ Business Media.

Jakobsson, M., O\&amp;apos;Regan, M., Mörth, C.-M., Stranne, C., Weidner, E., Hansson, J., et al. (2020). Potential links between Baltic Sea submarine terraces and groundwater seeping. Earth Surface Dynamics, 8(1), 1-15. https://doi.org/10.5194/esurf-8-1-2020

Jensen, J. B., Kuijpers, A., Bennike, O., Laier, T., \& Werner, F. (2002). New geological aspects for freshwater seepage and formation in Eckernförde Bay, western Baltic. Continental Shelf Research, 22(15), 2159-2173. https://doi.org/10.1016/S02784343(02)00076-6

Judd, A., \& Hovland, M. (2009). Seabed fluid flow: the impact on geology, biology and the marine environment. Cambridge University Press.

Kaleris, V., Lagas, G., Marczinek, S., \& Piotrowski, J. a. (2002). Modelling submarine 
groundwater discharge: an example from the western Baltic Sea. Journal of Hydrology, 265(1-4), 76-99. https://doi.org/10.1016/S0022-1694(02)00093-8

Karpen, V., Thomsen, L., \& Suess, E. (2004). A new 'schlieren' technique application for fluid flow visualization at cold seep sites. Marine Geology, 204(1-2), 145-159. https://doi.org/10.1016/S0025-3227(03)00370-0

Khandriche, A., \& Werner, F. (1995). Freshwater induced pockmarks in Bay of Eckernförde, western Baltic. Proceedings of the Third Marine Geological Conference "The Baltic," 2(149), 155-164.

Khandriche, A., Werner, F., \& Erlenkeuser, H. (1987). Auswirkungen der Oststürme vom Winter 1978/79 auf die Sedimentation im Schlickbereich der Eckernförder Bucht (Westliche Ostsee). Meyniana, 38, 125-151.

Koegler, F. C. (1967). Geotechnical properties of recent marine sediments from the Arabian Sea and the Baltic Sea. Marine Geotechnique. University of Chicago Press, Urbana, IL, 170-176.

Krastel, S., Berndt, C., \& Schneider von Deimling, J. (2017). Cruise Report R/V Alkor, Cruise No: AL501.

Lecher, A. L., Chien, C.-T., \& Paytan, A. (2016). Submarine groundwater discharge as a source of nutrients to the North Pacific and Arctic coastal ocean. Marine Chemistry, 186, 167-177. https://doi.org/10.1016/j.marchem.2016.09.008

Leifer, I., Luyendyk, B. P., Boles, J., \& Clark, J. F. (2006). Natural marine seepage blowout: Contribution to atmospheric methane. Global Biogeochemical Cycles, 20(3). https://doi.org/10.1029/2005GB002668

Lennartz, S. T., Lehmann, A., Herrford, J., Malien, F., Hansen, H.-P., Biester, H., \& Bange, H. W. (2014). Long-term trends at the Boknis Eck time series station (Baltic Sea), 19572013: does climate change counteract the decline in eutrophication? Biogeosciences, 11(22), 6323-6339. https://doi.org/10.5194/bg-11-6323-2014

Lewy, Z. (1975). Early diagenesis of calcareous skeletons in the Baltic Sea, Western Germany. Meyniana, 27, 29-33.

Loncke, L., Mascle, J., \& Fanil Scientific Parties. (2004). Mud volcanoes, gas chimneys, pockmarks and mounds in the Nile deep-sea fan (Eastern Mediterranean): geophysical evidences. Marine and Petroleum Geology, 21(6), 669-689. https://doi.org/10.1016/j.marpetgeo.2004.02.004

Maltby, J., Steinle, L., Löscher, C. R., Bange, H. W., Fischer, M. A., Schmidt, M., \& Treude, T. (2018). Microbial methanogenesis in the sulfate-reducing zone of sediments in the Eckernförde Bay, SW Baltic Sea. Biogeosciences, 15(1), 137-157. https://doi.org/10.5194/bg-15-137-2018

Marczinek, S., \& Piotrowski, J. A. (2002). Grundwasserströmung und-beschaffenheit im Einzugsgebiet der Eckernförder Bucht, Schleswig-Holstein. Grundwasser, 7(2), 101110.

Martens, C. S., Albert, D. B., \& Alperin, M. J. (1999). Stable isotope tracing of anaerobic methane oxidation in the gassy sediments of Eckernfoerde Bay, German Baltic Sea. American Journal of Science, 299, 589-610.

Milkert, D., \& Werner, F. (1997). Formation and distribution of storm layers in western Baltic Sea muds. Oceanographic Literature Review, 4(44), 326. 
Moore, W. S. (1996). Large groundwater inputs to coastal waters revealed by $226 \mathrm{Ra}$ enrichments. Nature, 380, 612-614.

Moore, W. S. (2010). The Effect of Submarine Groundwater Discharge on the Ocean. Annual Review of Marine Science, 2(1), 59-88. https://doi.org/10.1146/annurev-marine-120308081019

Moore, W. S., Sarmiento, J. L., \& Key, R. M. (2008). Submarine groundwater discharge revealed by 228Ra distribution in the upper Atlantic Ocean. Nature Geoscience, 1(5), 309-311. https://doi.org/10.1038/ngeo183

Mulder, T., \& Chochonat, P. (1996). Classification of offshore mass movements. Journal of Sedimentary Research, 66(1), 43-57.

Müller, H., von Dobeneck, T., Nehmiz, W., \& Hamer, K. (2011). Near-surface electromagnetic, rock magnetic, and geochemical fingerprinting of submarine freshwater seepage at Eckernförde Bay (SW Baltic Sea). Geo-Marine Letters, 31(2), 123-140. https://doi.org/10.1007/s00367-010-0220-0

Nittrouer, C. A., Lopez, G. R., Donelson Wright, L., Bentley, S. J., D’Andrea, A. F., Friedrichs, C. T., et al. (1998). Oceanographic processes and the preservation of sedimentary structure in Eckernförde Bay, Baltic Sea. Continental Shelf Research, 18(14-15), 1689-1714. https://doi.org/10.1016/S0278-4343(98)00054-5

Oehler, T., Tamborski, J., Rahman, S., Moosdorf, N., Ahrens, J., Mori, C., et al. (2019). DSi as a Tracer for Submarine Groundwater Discharge. Frontiers in Marine Science, 6, 563. https://doi.org/10.3389/fmars.2019.00563

Orsi, T. H., Werner, F., Milkert, D., Anderson, A. L., \& Bryant, W. R. (1996). Environmental overview of Eckernförde Bay, northern Germany. Geo-Marine Letters, 16, 140-147. https://doi.org/10.1007/BF01204501

Patiris, D. L., Tsabaris, C., Schmidt, M., Karageorgis, A. P., Prospathopoulos, A. M., Alexakis, S., \& Linke, P. (2018). Mobile underwater in situ gamma-ray spectroscopy to localize groundwater emanation from pockmarks in the Eckernförde bay, Germany. Applied Radiation and Isotopes, 140(August), 305-313. https://doi.org/10.1016/j.apradiso.2018.07.037

Post, V. E. A., Groen, J., Kooi, H., Person, M., Ge, S., \& Edmunds, W. M. (2013). Offshore fresh groundwater reserves as a global phenomenon. Nature, 504(7478), 71-78. https://doi.org/10.1038/nature12858

Reusch, A., Loher, M., Bouffard, D., Moernaut, J., Hellmich, F., Anselmetti, F. S., et al. (2015). Giant lacustrine pockmarks with subaqueous groundwater discharge and subsurface sediment mobilization. Geophysical Research Letters, 42(9), 3465-3473. https://doi.org/10.1002/2015GL064179

Riboulot, V., Imbert, P., Cattaneo, A., \& Voisset, M. (2019). Fluid escape features as relevant players in the enhancement of seafloor stability? Terra Nova, (July), 1-9. https://doi.org/10.1111/ter.12425

Ritger, S., Carson, B., \& Suess, E. (1987). Methane-derived authigenic carbonates formed by subduction-induced pore-water expulsion along the Oregon/Washington margin. Geological Society of America Bulletin, 98, 147. https://doi.org/10.1130/00167606(1987)98<147:MACFBS>2.0.CO;2

Rößler, D. (2006). Reconstruction of the Littorina transgression in the Western Baltic Sea. 
Marine Science Reports (IOW), 67, 1-111.

Sauter, E., Laier, T., Andersen, C. E., Dahlgaard, H., \& Schlüter, M. (2001). Sampling of sub-seafloor aquifers by a temporary well for CFC age dating and natural tracer investigations. Journal of Sea Research, 46(2), 177-185. https://doi.org/10.1016/S13851101(01)00080-6

Sauter, E., Schlüter, M., Sedyn, P. L., Fraser, N., \& Fogt, P. (2003). AUV multi-technique surveying of submarine freshwater seeps-high and ultra-high resolution acoustic and CTD mapping of pockmark sites in Eckernförde Bay, Western Baltic Sea. Sea Technology, 44(3), 49-52.

Schlüter, M., Sauter, E. J., Andersen, C. E., Dahlgaard, H., \& Dando, P. R. (2004). Spatial distribution and budget for submarine groundwater discharge in Eckernförde Bay (Western Baltic Sea). Limnology and Oceanography, 49(1), 157-167.

Schneider von Deimling, J. (2014). R/V Alkor Cruise Report AL447.

Schneider von Deimling, J. (2019). Cruise Report RV Littorina, Cruise No.: L19/05. Christian-Albrechts-Universität zu Kiel.

Schneider von Deimling, J., Weinrebe, W., Tóth, Z., Fossing, H., Endler, R., Rehder, G., \& Spieß, V. (2013). A low frequency multibeam assessment: Spatial mapping of shallow gas by enhanced penetration and angular response anomaly. Marine and Petroleum Geology, 44, 217-222. https://doi.org/10.1016/j.marpetgeo.2013.02.013

Scholten, J. C., Osvath, I., \& Pham, M. K. (2013). 226Ra measurements through gamma spectrometric counting of radon progenies: How significant is the loss of radon? Marine Chemistry, 156, 146-152. https://doi.org/10.1016/j.marchem.2013.03.001

Schüler, F. (1952). Untersuchungen über die Mächtigkeit von Schlickschichten mit Hilfe des Echographen. Deutsche Hydrographische Zeitschrift, 5(5-6), 220-231.

Seager, R., Ting, M., Held, I., Kushnir, Y., Lu, J., Vecchi, G., et al. (2007). Model Projections of an Imminent Transition to a More Arid Climate in Southwestern North America. Science, 316(5828), 1181-1184. https://doi.org/10.1126/science.1139601

Seeberg-Elverfeldt, J., Schlüter, M., Feseker, T., \& Kölling, M. (2005). Rhizon sampling of porewaters near the sediment-water interface of aquatic systems. Limnology and Oceanography: Methods, 3(8), 361-371.

Seibold, E., Exon, N., Hartmann, M., Kögler, F.-C., Krumm, H., Lutze, G. F., et al. (1971). Marine geology of Kiel bay. In Sedimentology of Parts of Central Europe, Guidebook, 8th International Sedimentological Congress, Heidelberg (pp. 209-235).

Shaban, A., Khawlie, M., Abdallah, C., \& Faour, G. (2005). Geologic controls of submarine groundwater discharge: application of remote sensing to north Lebanon. Environmental Geology, 47(4), 512-522.

Sills, G. C., \& Wheeler, S. J. (1992). The significance of gas for offshore operations. Continental Shelf Research, 12(10), 1239-1250. https://doi.org/10.1016/02784343(92)90083-V

Silva, A. J., \& Brandes, H. G. (1998). Geotechnical properties and behavior of high-porosity, organic-rich sediments in Eckernförde Bay, Germany. Continental Shelf Research, 18(14-15), 1917-1938.

Smetacek, V. (1985). The annual cycle of Kiel Bight plankton: A long-term analysis. Estuaries, 8(2A), 145-157. 
Smetacek, V., von Bodungen, B., von Brockel, K., Knoppers, B., Martens, P., Peinert, R., et al. (1987). Seasonality of plankton growth and sedimentation. Seawater-Sediment Interactions in Coastal Waters. Springer, Berlin, 34-56.

Solomon, E. A., Kastner, M., MacDonald, I. R., \& Leifer, I. (2009). Considerable methane fluxes to the atmosphere from hydrocarbon seeps in the Gulf of Mexico. Nature Geoscience, 2(8), 561-565. https://doi.org/10.1038/ngeo574

Sommer, S., Linke, P., Pfannkuche, O., Schleicher, T., Schneider von Deimling, J., Reitz, A., et al. (2009). Seabed methane emissions and the habitat of frenulate tubeworms on the Captain Arutyunov mud volcano (Gulf of Cadiz). Marine Ecology Progress Series, 382, 69-86. https://doi.org/10.3354/meps07956

Steinle, L., Maltby, J., Treude, T., Kock, A., Bange, H. W., Engbersen, N., et al. (2017). Effects of low oxygen concentrations on aerobic methane oxidation in seasonally hypoxic coastal waters. Biogeosciences, 14(6), 1631-1645. https://doi.org/10.5194/bg14-1631-2017

Stieglitz, T. (2005). Submarine groundwater discharge into the near-shore zone of the Great Barrier Reef, Australia. Marine Pollution Bulletin, 51(1-4), 51-59. https://doi.org/10.1016/j.marpolbul.2004.10.055

Tamborski, J. J., Rogers, A. D., Bokuniewicz, H. J., Cochran, J. K., \& Young, C. R. (2015). Identification and quantification of diffuse fresh submarine groundwater discharge via airborne thermal infrared remote sensing. Remote Sensing of Environment, 171, 202217.

Treude, T., Krüger, M., Boetius, A., \& Jørgensen, B. B. (2005). Environmental control on anaerobic oxidation of methane in the gassy sediments of Eckernförde Bay (German Baltic). Limnology and Oceanography, 50(6), 1771-1786.

Viso, R., McCoy, C., Gayes, P., \& Quafisi, D. (2010). Geological controls on submarine groundwater discharge in Long Bay, South Carolina (USA). Continental Shelf Research, 30, 335-341. https://doi.org/10.1016/j.csr.2009.11.014

Wefer, G., Balzer, W., Bodungen, B. v, \& Suess, E. (1987). Biogenic carbonates in temperate and subtropical environments: production and accumulation, saturation state and stable isotope composition. In Seawater-Sediment Interactions in Coastal Waters (pp. 263302). Springer.

Werner, F. (1978). Depressions in mud sediments (Eckernförde Bay, Baltic Sea) related to sub-bottom and currents. Meyniana, 30, 99-104.

Werner, F., Erlenkeuser, H., Grafenstein, U. v, McLean, S., Sarnthein, M., Schauer, U., et al. (1987). Sedimentary records of benthic processes. In Seawater-sediment interactions in coastal waters (pp. 162-262). Springer.

Wever, T. F., Abegg, F., Fiedler, H. M., Fechner, G., \& Stender, I. H. (1998). Shallow gas in the muddy sediments of Eckernförde Bay, Germany. Continental Shelf Research, 18, 1715-1739.

Wever, T. F., Lühder, R., Voß, H., \& Knispel, U. (2006). Potential environmental control of free shallow gas in the seafloor of Eckernförde Bay, Germany. Marine Geology, 225(14), 1-4. https://doi.org/10.1016/j.margeo.2005.08.005

Whiticar, M. J. (2002). Diagenetic relationships of methanogenesis, nutrients, acoustic turbidity, pockmarks and freshwater seepages in Eckernförde Bay. Marine Geology, 
182(1-2), 29-53. https://doi.org/10.1016/S0025-3227(01)00227-4

Whiticar, M. J., \& Werner, F. (1981). Pockmarks: Submarine vents of natural gas or freshwater seeps? Geo-Marine Letters, 1(3-4), 193-199.

https://doi.org/10.1007/BF02462433

Wilson, J., \& Rocha, C. (2012). Regional scale assessment of Submarine Groundwater Discharge in Ireland combining medium resolution satellite imagery and geochemical tracing techniques. Remote Sensing of Environment, 119, 21-34.

Yamamoto, S., Alcauskas, J. B., \& Crozier, T. E. (1976). Solubility of methane in distilled water and seawater. Journal of Chemical and Engineering Data, 21(1), 78-80. 


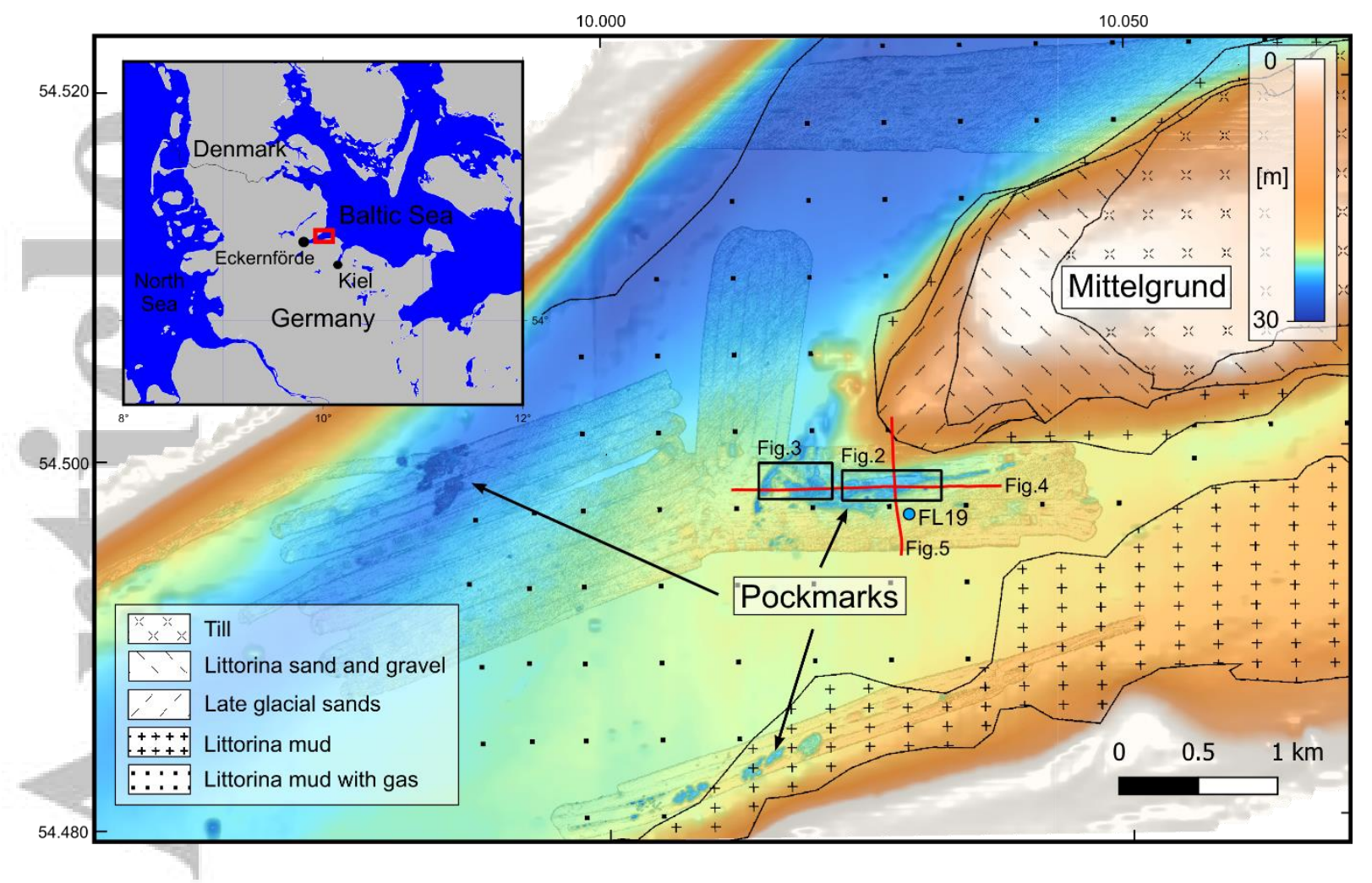

Figure 1: Overview bathymetric map of Eckernförde Bay with geological surface sediments overlaid, as described by Jensen et al. (2002). High resolution bathymetry from Cruise AL447 (2014) overlays the regional bathymetry kindly provided by the Federal Marine Hydrographic agency. The sediment background core FL19 is indicated by the blue dot. 

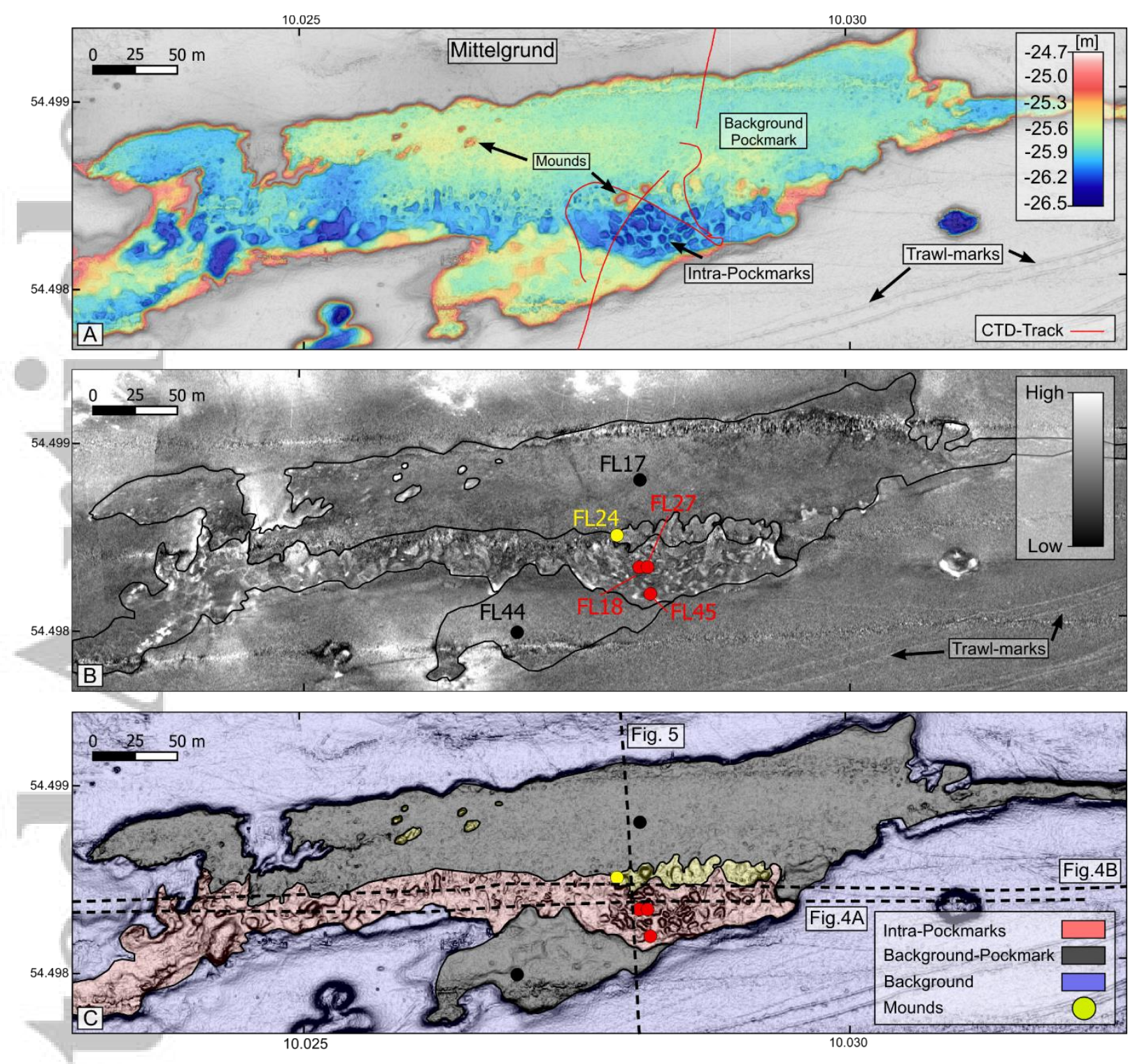

Figure 2: Bathymetric overview of the eastern Mittelgrund pockmark (data from cruise AL447 in October 2014). A: Bathymetric map highlighting the large scale eastern Mittelgrund pockmark (coloured region) and its internal intra-pockmark and background pockmark regime. Example mounds are also labelled, and the red line shows the towed CTDtracks. B: Corrected $(300 \mathrm{kHz})$ backscatter image showing the high-amplitude responses of the intra-pockmarks. Coloured dots show core locations and the black lines delineate the classification regime shown in (C). C: Slope map overlaid with pockmark classification (semi-transparent colours) as described in the text. Dashed lines show the location of the subbottom profiler data displayed in Figure 4 and 5 and coloured dots show core locations. 

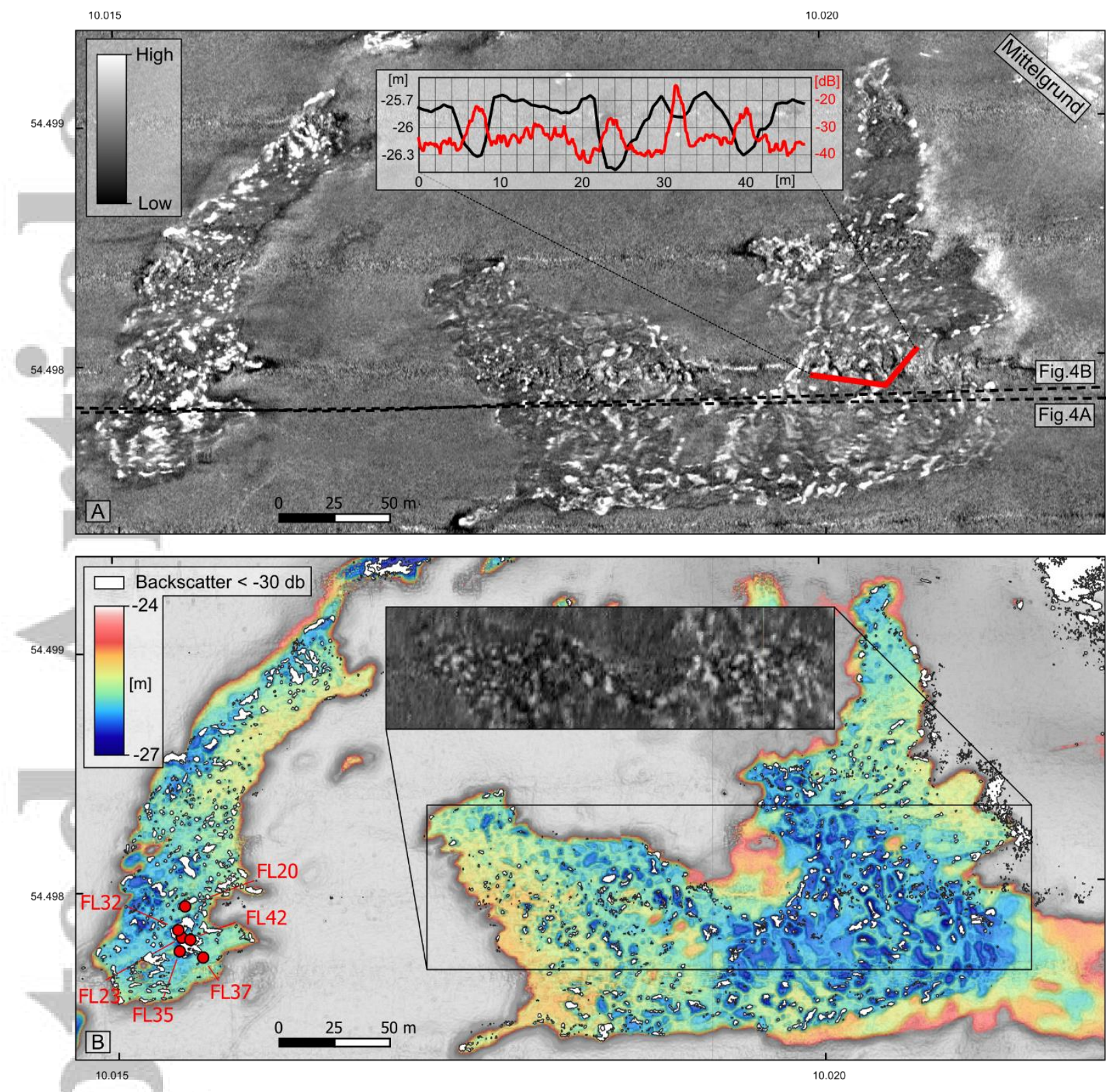

Figure 3: A: $300 \mathrm{kHz}$ backscatter image of the western Mittelgrund pockmark showing the patchy strong backscatter strength of the intra-pockmarks (Cruise AL447, October 2014). Inset graph shows the clear inverse correlation between relative backscatter strength $(\mathrm{dB})$ and seafloor elevation $(\mathrm{m})$. B: Bathymetry of the pockmark with strong backscatter values $(<-30$ $\mathrm{dB}$ ) overlain in white. Inset shows the $180 \mathrm{kHz}$ backscatter image of cruise L1905, May 2019. 


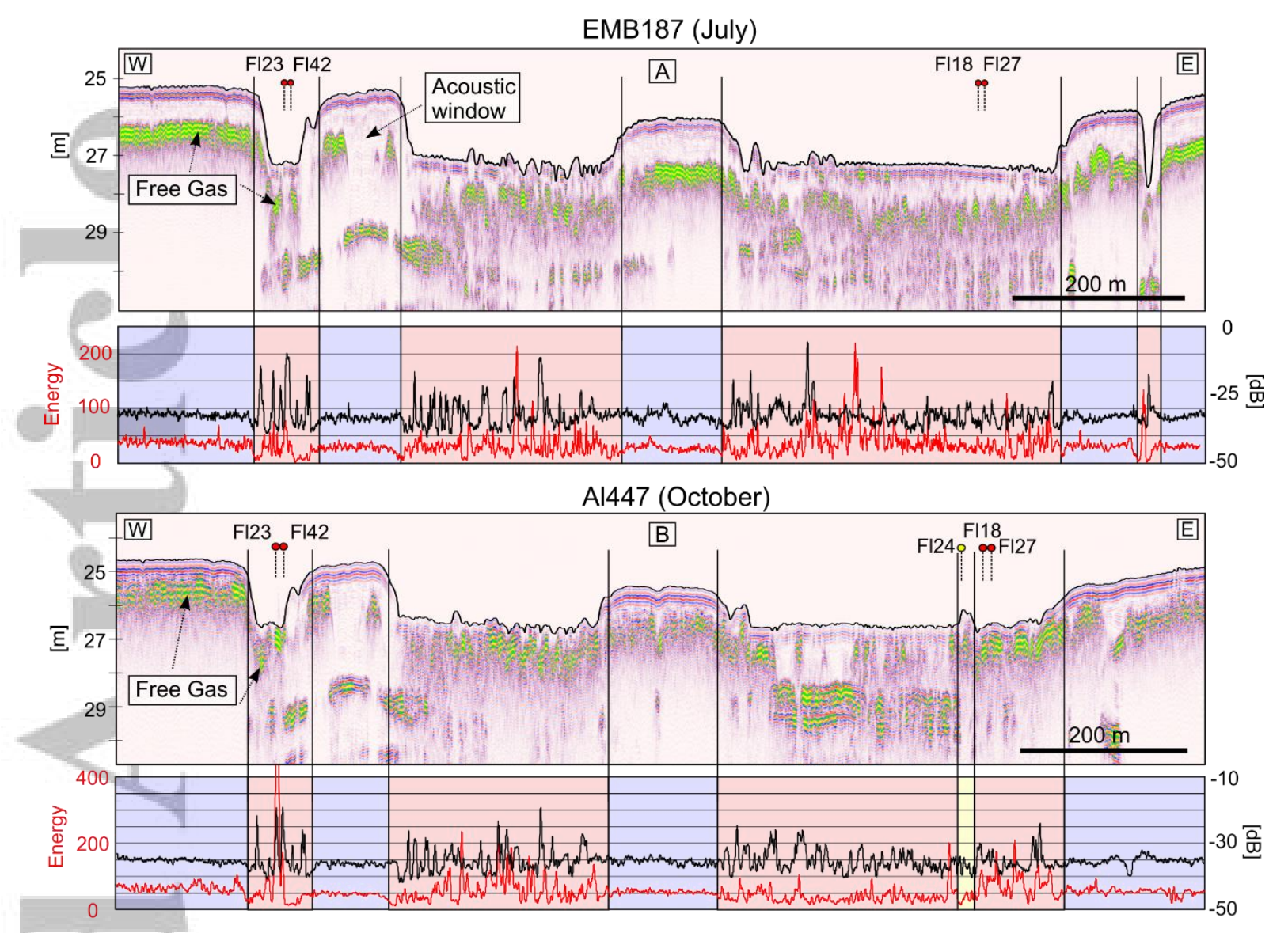

Figure 4: Innomar subbottom profiler data across the Mittelgrund pockmarks, with the energy extracted from the upper $50 \mathrm{~cm}$ beneath the seafloor in red and the along-track multibeam backscatter in black (in the accompanying plots). A: Profile acquired during July 2018, B:

Profile acquired during October 2014 (locations in Figures 1, 2 \& 3). Sediment core locations along the profile are marked by labelled dots. Semi-transparent colours in the dots and behind the energy plots are representative of different seafloor classifications as defined in Figure $2 \mathrm{C}$. 


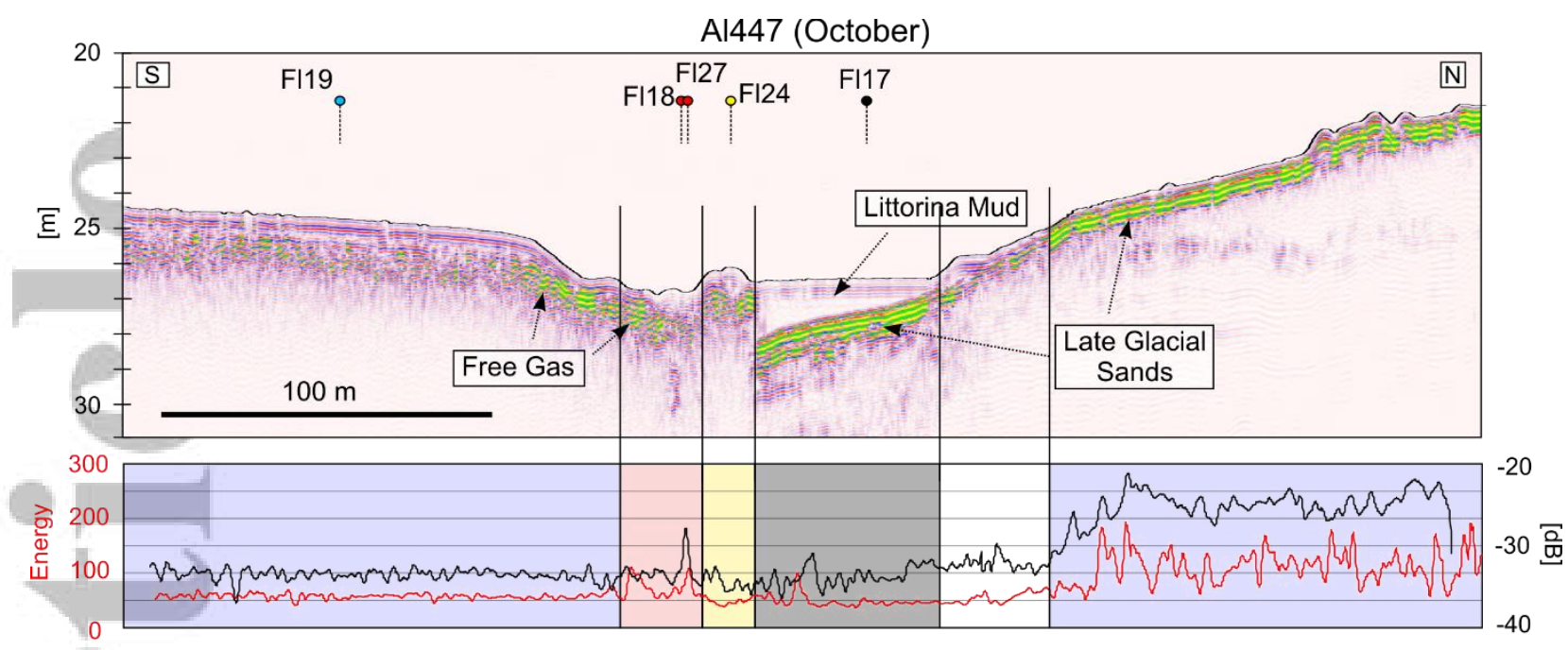

Figure 5: Top: North-South profile through the pockmarks covering Mittelgrund in the North and the inner bay in the South. Location of the profile is given in Figure 1 and 2. Bottom: the energy extracted from the upper $50 \mathrm{~cm}$ beneath the seafloor is displayed in red and the alongtrack multibeam backscatter in black. Sediment core locations along the profile are marked by labelled dots. Semi-transparent colours in the dots and behind the energy plots are representative of different seafloor classifications as defined in Figure 2C. 


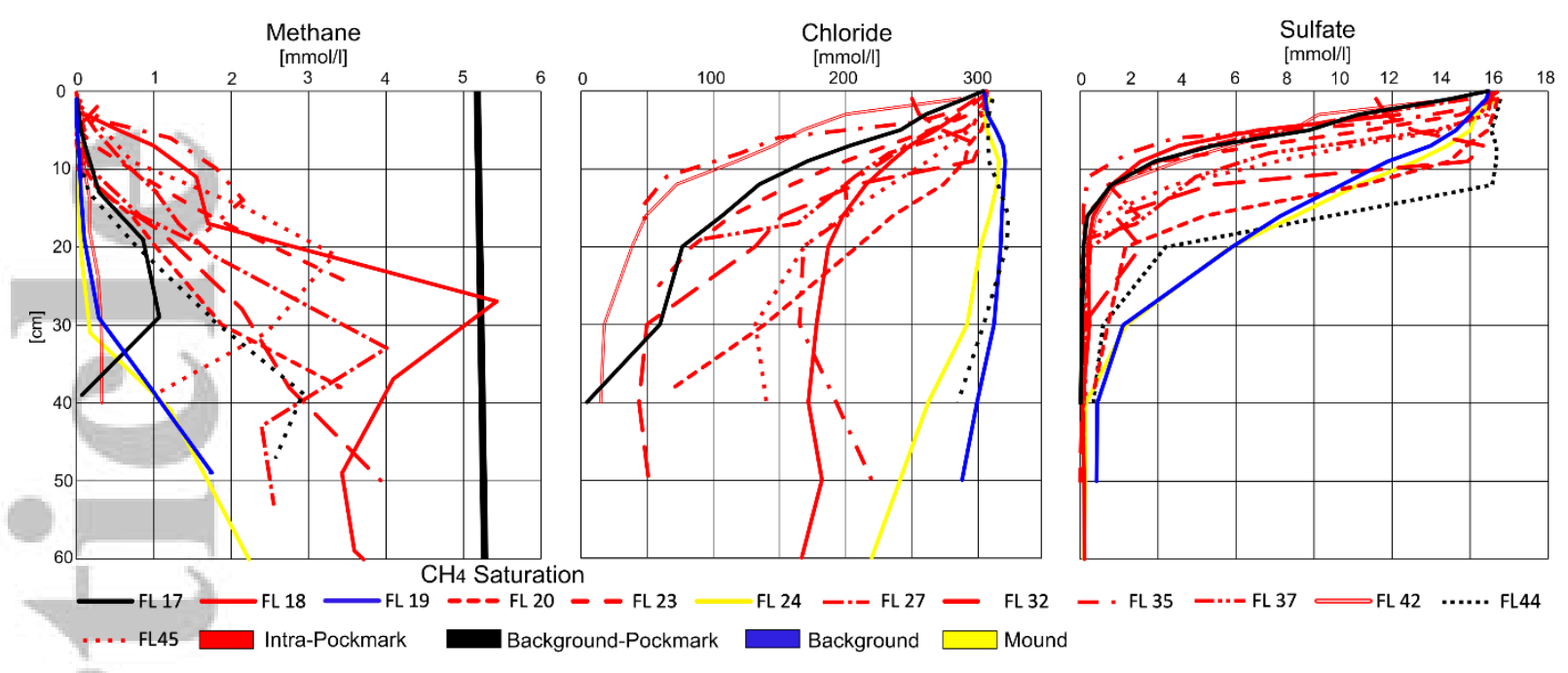

Figure 6: Porewater methane, chloride and sulfate concentrations in all sediment cores collected, colour-coded by regime. 

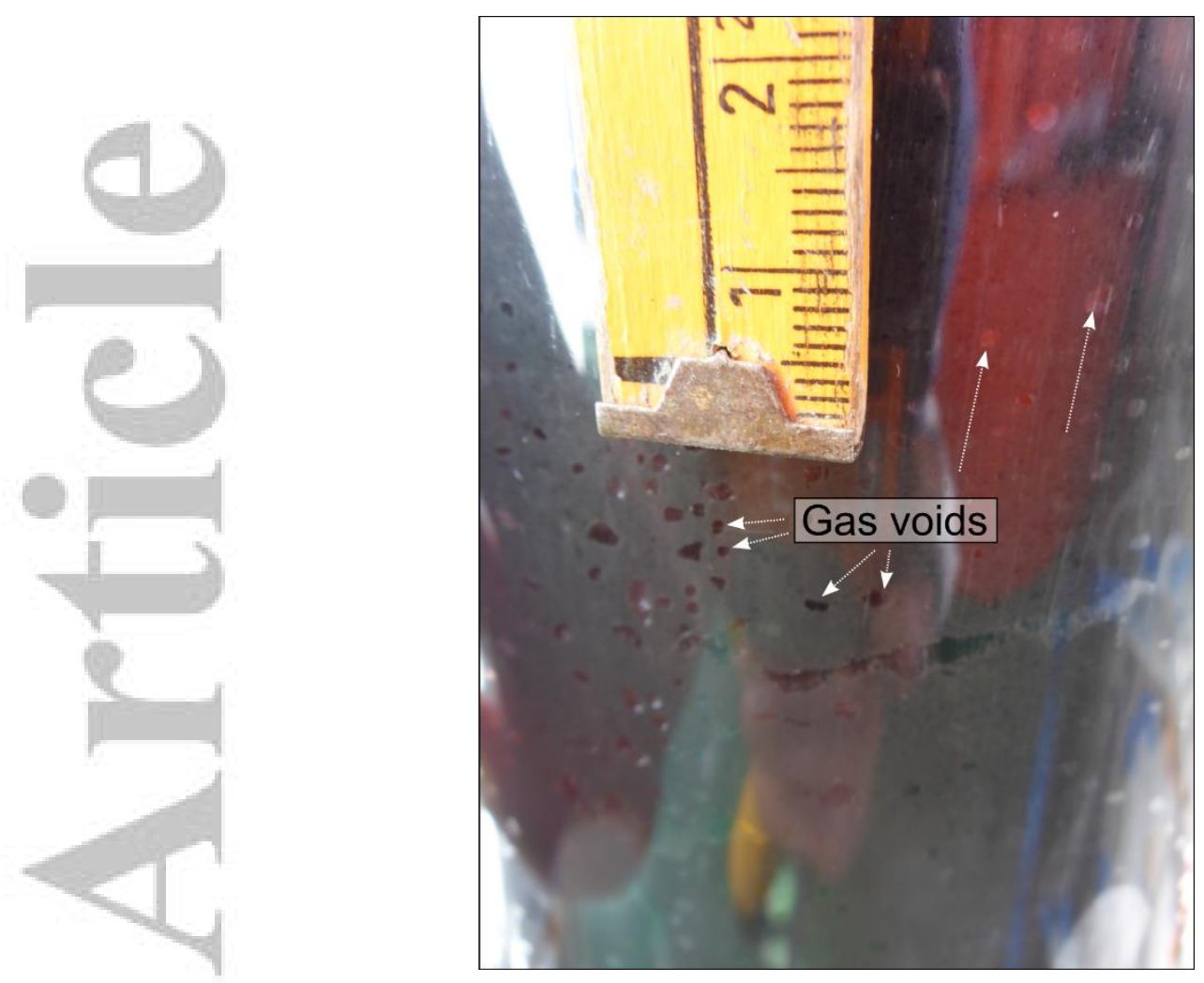

Figure 7: Voids in the sediment cores containing free gas immediately after core recovery (core FL18). 